Research Report No. 16/2008

\title{
Regulating Payday Lenders in Canada: Drawing on American Lessons
}

Stephanie Ben-Ishai

Osgoode Hall Law School of York University, sbenishai@osgoode.yorku.ca

Follow this and additional works at: http://digitalcommons.osgoode.yorku.ca/clpe

\section{Recommended Citation}

Ben-Ishai, Stephanie, "Regulating Payday Lenders in Canada: Drawing on American Lessons" (2008). Comparative Research in Law es Political Economy. Research Paper No. 16/2008.

http://digitalcommons.osgoode.yorku.ca/clpe/189 


\section{Comparative Research in Law \& Political Economy}

\section{Stephanie Ben-Ishai}

Regulating Payday Lenders in Canada: Drawing on American Lessons

EDTORS: Peer Zumbansen (Osgoode Hall Law School, Toronto, Director, Comparative Research in Law and Political Economy, York University), J ohn W. Cioffi (University of California at Riverside), Lindsay Krauss (Osgoode Hall Law School, Toronto, Production Editor)

This paper can be downloaded without charge from the Social Science Research Network Electronic Library at: http:// ssrn. com/ abstractid=1128147 

CLPE Research Paper 16/2008

Vol. 04 No. 03 (2008)

\title{
Stephanie Ben-Ishai
}

\section{Regulating PAyday Lenders in CANAdA: DRAWING ON AMERICAN LESSONS}

\begin{abstract}
The regulation of payday loans holds the potential of extending the benefits of regulating overindebtness, currently provided via bankruptcy legislation to the middle-class, to lower income debtors. This potential needs to be balanced against lower income debtors' need for credit and the corresponding benefits resulting from access to credit provided by alternative credit markets, such as the payday lending market. Unlike the United States, where payday lenders have more locations than Starbucks and McDonalds combined, and payday lending regulation is up there with Vampire Weekend and the Tipping Point as an attention grabbing pop-culture reference, payday lending is relatively new, underdeveloped and unregulated in Canada. Over the last year, in the wake of a recent amendment to the Canadian Criminal Code, that would see payday lenders exempted from the 60 per cent criminal rate of interest in provinces where payday lenders are provincially regulated, Canadian provinces have began to regulate and put forth regulatory proposals for a previously unregulated area. This exercise has been attempted in the context of limited recent domestic analysis of the payday lending industry, borrowers and regulatory options. Accordingly, this article sets out to fill this void. The article draws on the American experience with payday lending and payday lending regulation, and also a first-hand experience of attempting to obtain a payday loan in Toronto, Ontario, to evaluate the current provincial reform efforts.
\end{abstract}

Keywords: payday loans, regulation, bankruptcy, alternative credit markets

JEL classification: K23, K35 


\section{Author Contact:}

\section{Stephanie Ben-Ishai}

Associate Professor, Osgoode Hall Law School, York University 4700 Keele St

Toronto, Ontario, Canada

Email: sbenishai@osgoode.yorku.ca 


\title{
Regulating Payday Lenders in CANADA: DRAWING ON AMERICAN LESSONS
}

\author{
Stephanie Ben-Ishai ${ }^{*}$
}

Payday loans are a relatively new phenomenon in Canada. They are typically short-term, single-payment loans: the lender agrees to lend the debtor a certain amount of money, in return for the promise of repayment (usually on a cheque from the debtor, post-dated to the date of his or her next paycheque) and certain fees. Payday lending has been vilified in recent media coverage of subprime or fringe lending. Often payday lending is described as "predatory." Three key arguments are made in support of the "predatory" label: payday lenders charge too much money; payday lenders target the poor; and payday lenders lie to customers (or omit information). At the same time, payday lending, like other forms of fringe lending in the past, plays a role in servicing and giving access to credit to an otherwise neglected segment of the market: minority and disenfranchised groups.

In the wake of a recent amendment to the federal Criminal Code that would see payday lenders exempted from the 60 per cent criminal rate of interest in provinces where payday lenders are provincially regulated, Canadian provinces have begun to regulate and put forth regulatory proposals for a previously unregulated area. This exercise has been attempted in the context of limited recent domestic analysis of the payday lending industry, borrowers and regulatory options. Accordingly, this article sets out to fill this void by drawing on the American experience with payday lending and payday lending regulation, and also a first-hand experience of attempting to obtain a payday loan in Toronto, Ontario. First an introduction to the "payday lending debate" is provided. Second,

\footnotetext{
* Associate Professor, Osgoode Hall Law School, York University, Toronto. I am grateful for comments from Tony Duggan, Benjamin Geva, Stephen Lubben, Jacob Ziegel, and for the input received at a presentation of an earlier form of this article to the Faculty Colloquium Workshop at Seton Hall Law School. The splendid research assistance provided by Virginia Torrie, Catherine Nowak, and Zohar Levy is gratefully acknowledged. Research for this article is current to April 8, 2008.
} 
the business model for payday lenders operating in Canada is set out. Third, the evolving Canadian regulatory scheme is outlined. The fourth section of the article documents six attempts to obtain loans from payday lenders in Toronto, Ontario. The fifth section of the article provides an analysis of the American tools used for regulating payday lenders. The sixth section of the article evaluates the evolving Canadian regulatory scheme in light of lessons drawn from the use of the various regulatory tools in the United States and the visits to Canadian payday lenders. Part seven concludes with reflections on two possible directions for future research: the role of Canadian corporate and securities law and the corporate social responsibility movement in facilitating a change in the practices of payday lenders and the potential of American Community Reinvestment Act style legislation in Canada.

\section{An InTRoduction to Payday Lending}

One of the most common forms of attack leveled against payday lenders begins with the author recounting the story of a borrower, usually a woman of modest means, often of a minority group, who takes out a payday loan for a small amount to make ends meet and ends up paying thousands of dollars in fees without ever paying off the principal. ${ }^{1}$ The interest charged by payday lenders is generally over 400 per cent annual percentage rate (APR), ${ }^{2}$ and other fees including rollover or extension fees

\footnotetext{
${ }^{1}$ See for example: Patricia Turner ended up paying \$840 in extension fees for a \$300 loan which she was not able to pay down in Charles Bruch, "Taking the Pay Out of Payday Loans: Putting an End to the Usurious and Unconscionable Interest Rates Charged by Payday Lenders” (2001) 69 U. Cin. L. Rev. 1257; Sandra Harris’s experience with payday lenders resulted in her car being repossessed and wages garnered in Michael Bertics, "Fixing Payday Lending: The Potential of Greater Bank Involvement” (2005) 9 N.C. Banking Inst. 133; most newspaper articles on payday lenders also start with a similar story, like Margaret Smith in "Caught in the Loan Trap: Paying it Back Can Become a Vicious Circle” (19 June 2004) Toronto Star.

2 Creola Johnson, "Payday Loans: Shrewd Business or Predatory Lending?” (2002) 87 Minn. L. Rev. 1 at 27; Kathleen E. Keest \& Elizabeth Renuart, The Cost of Credit: Regulation and Legal Challenges, 2d ed. (Boston: National Consumer Law Center, 2000) at 297; Aaron Huckstep, "Payday Lending: Do Outrageous Prices Necessarily Mean Outrageous Profits?” (2006) 12 Fordham J. Corp. \& Fin. L. 203 at 208; in Canada the
} 
can further increase the cost of a loan. Given that in Canada, the federal criminal usury rate is 60 per cent, the rates charged even by compliant payday lenders are far above what mainstream credit providers charge. Because the rate of interest charged is so high, the payday lending transaction has been described as "one-sided," and not extending any real benefit to payday loan consumers. ${ }^{3}$ Further, payday lenders structure their loans in such a way as to be most profitable to them. For example, the date on which the loan is due is usually the day before the borrower's paycheque arrives, so lenders are able to charge additional fees for repayment after the due date. ${ }^{4}$

Even if these fees and interest were reasonable for a single transaction, the fact that the majority of payday lenders are repeat customers means that many borrowers are trapped in the scheme for the long haul. ${ }^{5}$ Instead of encouraging customers to pay off their debt, payday lenders extend loans (for a hefty fee) or allow borrowers to take out new loans to repay the old ones; ${ }^{6}$ many payday lenders encourage customers to take out multiple loans at the same time. ${ }^{7}$ In fact, the very nature of the payday loan and its short duration (typically two weeks), means that rolling over loans is often inevitable for payday borrowers. ${ }^{8}$ This rollover feature can cause consumers to "accumulate an unmanageable cycle of debt."9

As two American commentators argue, payday lenders "feed off poverty and financial exclusion.” 10 For example, the average American payday loan customer is likely to be a member of a minority group from an inner city neighborhood. ${ }^{11}$ Some sources (often payday lenders or organizations

situation is similar, as reflected in Protecting Canadians' Interest: Reining in the Payday Lending Industry (ACORN Canada: Vancouver, 2004) at 1 [“ACORN Report”].

${ }^{3}$ Bruch, supra note 1 at 1279.

${ }^{4}$ ACORN Report, supra note 2 at 10.

${ }^{5}$ Bruch, supra note 1 at 1280; Huckstep, supra note 2 at 208.

${ }_{7}^{6}$ Bruch, supra note 1 at 1281.

${ }^{7}$ Bertics, supra note 1 at 138-9.

${ }^{8}$ Ibid. at 138.

${ }^{9}$ Carmen Butler \& Niloufar Park, "Mayday Payday: Can Corporate Social Responsibility Save Payday Lenders?” (2005) 3 Rutgers J.L. \& Urb. Pol’y 119 at 122.

${ }^{10}$ H. Palmer, Profiting from Poverty: Why Debt is Big Business in Britain (New Economics Foundation: London, 2002).

11 Laurie Burlingame, "A Pro-Consumer Approach to Predatory Lending: Enhanced Protection Through Federal Legislation and New Approaches to Education” (2006) 60 
representing them) paint a more flattering picture of payday borrowers, suggesting that payday customers make an average salary of around $\$ 35,000$, a third of them own their homes, and that they have been in their jobs and homes for around 4 years. ${ }^{12}$ However, this description of the demographic is discredited by most academics, as numbers like that are sometimes reflective of county-wide averages rather than actual payday loan customers. ${ }^{13}$

Often, payday loan customers have low fixed incomes. ${ }^{14}$ Their income leaves little room for coping with emergencies or additional expenses. The target customers for payday lenders rarely have the surplus in their budget they would need to pay back the interest fees charged by the lenders - if they did, they would not be turning to payday lenders in the first place. ${ }^{15}$

One of the other accusations most often levied against payday lenders is that they prevent customers from making educated choices or shopping around because they are not clear about the fees they charge. Many payday lenders hide basic information about their loans from customers. ${ }^{16}$ Payday lenders have also been known to avoid disclosure of information like interest rates or finance charges until right before the agreement is to be signed. ${ }^{17}$ According to one study, payday lenders in Ohio do not typically disclose the triple digit interest rates they charge until after the payday loan agreement is signed. ${ }^{18}$ Other American payday loan providers refused to respond to an oral request from a borrower who

Consumer Fin. L.Q. Rep. 460 at 462; Lynn Drysdale \& Kathleen Keest, "The TwoTiered Consumer Financial Services Marketplace: The Fringe Banking System and Its Challenge to Current Thinking About the Role of Usury Laws in Today’s Society” (2000)

51 S.C. L. Rev. 589 at 591.

12 Drysdale \&Keest, ibid. at 627.

${ }^{13}$ Ibid. at 629 .

${ }^{14}$ Ibid. at 630, 631-2; Kurt Eggert "Lashed to the Mast and Crying for Help: How SelfLimitation of Autonomy Can Protect Elders from Predatory Lending” (2003) 36 Loy. L.A. L. Rev. 693.

${ }^{15}$ Bruch, supra note 1 at 1280.

${ }^{16}$ Bertics, supra note 1 at 139 citing Johnson, supra note 2 at 32; Butler, supra note 9 at 121.

${ }^{17}$ Christopher L. Peterson, “Truth, Understanding, and High Cost Consumer Credit: The Historical Context of the Truth in Lending Act” (2003) 55 Fla. L. Rev. 807 at 898.

${ }^{18}$ Johnson, supra note 2 at 32. 
wanted to know the APR of their loan. ${ }^{19}$ In another survey, only 37 per cent of payday lenders gave an "even marginally accurate APR" when a telephone inquiry was made about the cost of credit. ${ }^{20}$

The misleading advertising is even more egregious in situations where there is a legitimately better option - for example, in the context of the American military, where active duty personnel can receive interest-free emergency loans but still turn to payday lenders because of their "powerful marketing campaigns."21

Even for borrowers who are somewhat aware that there are statutory limits on interest that can be charged (in some American states, and in Canada until the amendments to s. 347 of the Criminal Code), payday lenders can still convince them to borrow without violating their rights since they will often charge very little "interest" and collect the remainder of their money as various types of fees. ${ }^{22}$ However, where the issue has been litigated, courts have recognized that these fees are interest, and generally classified them as such when deciding cases. ${ }^{23}$

There remains an upside to payday lending. Consider the role that payday lending plays in servicing and giving access to credit to an otherwise neglected segment of the market. Many customers of payday loans feel

19 Jean Ann Fox \& Edmund Mierzwinski, "Rent-A-Bank: How Banks Help Payday Lenders Evade State Consumer Protections,” the 2001 Payday Lender Survey and Report, (CFA \& State Public Interest Research Groups), online: <http://www.uspirg.org/reports/rentabank/paydayreportnov13.pdf> at 13.

${ }^{20}$ Bruch, supra note 1 at 1284.

${ }^{21}$ Drysdale \& Keest, supra note 11 at 630-1.

${ }^{22}$ ACORN report, supra note 2 at 11; Bruch, supra note 1 at 1276.

${ }^{23}$ Bruch, supra note 1 at 1276; Drysdale \& Keest, supra note 11 at 642 . The issue has not been fully litigated in Canada, however it is notable that a number of class actions have been recently certified based on restitutionary claims arising from the alleged charging of criminal rates of interest (under the earlier version of section 347 of the Criminal Code) on payday loans. See: McCutcheon v. The Cash Store Inc., [2006] O.J. No. 1860 (S.C.J.); Smith v. National Money Mart Co., [2007] O.J. No. 46 (S.C.J.); MacKinnon v. National Money Mart Co., [2005] B.C.J. No. 399 (S.C.); Kilroy v. A OK Payday Loans Inc., [2006] B.C.J. No. 1885 (S.C.); Bodnar v. Payroll Loans Ltd., [2006] B.C.J. No. 1705 (S.C.); Tracy v. Instaloans Financial Solutions Centres (B.C.) Ltd., [2006] B.C.J. No. 1639 (S.C.); Bodnar v. The Cash Store Inc., [2005] B.C.J. No. 1904 (S.C.); and Ayrton v. PRL Financial (Alta.) Ltd., [2006] A.J. No. 296 (C.A.). 
they have nowhere else to go. ${ }^{24}$ Payday lenders target consumers who have low income and too little collateral to borrow from a bank. ${ }^{25}$ Banks also do not offer short-term, small loans, and very often payday loan customers are not able to qualify for a credit card. ${ }^{26}$ Customers frequently need the money for an emergency or unexpected expense, ${ }^{27}$ and are unable to find another source of credit with which to meet the cost. Pawnbrokers require something to pawn, and borrowing from family members may be too embarrassing or difficult. ${ }^{28}$ Though payday lenders do charge a high rate of interest, some have argued that they are still cheaper than writing a cheque that is returned dishonoured, ${ }^{29}$ and to completely outlaw payday lenders may force this vulnerable group to turn to loan sharks and more criminal lenders. ${ }^{30}$

Payday lenders are also quick and easy to access, and make minority and disenfranchised groups feel more at ease. Sometimes, customers will choose payday loans over a bank because they are more friendly and accessible, providing more immediate liquidity. ${ }^{31}$ Other times, banks are just too inconvenient - payday lenders have more flexible hours than banks, and better locations. ${ }^{32}$ For example, in Toronto and Vancouver, banks have tended to close more branches in lower income areas, and "payday lenders are moving aggressively into this competitive vacuum."33 Payday lenders also make more of an effort to solicit the local community

\footnotetext{
${ }^{24}$ Scott Andrew Schaaf, "From Checks to Cash: The Regulation of the Payday Lending Industry” (2001) 5 N.C. Banking Inst. 339 at 344; Iain Ramsay, “Access to Credit in the Alternative Consumer Credit Market” (Paper prepared for Office of Consumer Affairs, Industry Canada, February 2000), online: <http://cmsweb.ca/epic/internet/incmccmc.nsf/vwapj/ramsay_e.pdf/\$FILE/ramsay_e.pdf $>$ at 17.

${ }^{25}$ Butler \& Park, supra note 9 at 123.

${ }^{26}$ Schaaf, supra note 24 at 343.

27 Ibid. at 346.

${ }^{28}$ Huckstep, supra note 2 at 209.

${ }^{29}$ Schaaf, supra note 24 at 344

${ }^{30}$ Ibid. at 344.

${ }^{31}$ Ibid. at 344.

32 Susan MacDonnell, Losing Ground: The Persistent Growth of Family Poverty in Canada's Largest City (Toronto: United Way of Greater Toronto, 2007) at 49.

${ }^{33}$ ACORN report, supra note 2 at 15.
} 
than banks, and will often have employees who speak the language of the dominant ethnic group of the neighbourhood. ${ }^{34}$

\section{THE BUSINESS MODEL FOR PAYDAY LENDERS IN CANADA}

The main line of business for payday lenders is, as the name implies, making payday loans. Those are typically short-term, single-payment loans: The lender agrees to lend the debtor a certain amount of money, in return for the promise of repayment (usually on a cheque from the debtor, post-dated to the date of his or her next paycheque) and certain fees. The fees are typically $\$ 15-25$ per $\$ 100$ of loan granted, and are fixed without regard to the term of the loan; ${ }^{35}$ it costs a consumer on average $\$ 50$ to take out a $\$ 300$ loan for 14 days. ${ }^{36}$ The average loan is about $\$ 280$ for around a period of 10 days. $^{37}$

The lender determines the creditworthiness of the debtor through basic documentation - proof of identity that shows the borrower has attained the age of majority and the borrower's address, and proof of a steady income and a chequing account. ${ }^{38}$ Many payday lenders advertise that they do not

\footnotetext{
${ }^{34}$ Lesly Jean-Paul \& Luxman Nathan, “Check Cashers: Moving from the Fringes to the Financial Mainstream, Communities and Banking” (Federal Reserve Bank of Boston, Boston, Mass.), Summer 1999, online: Federal Reserve Bank of Boston, $<$ http://www.bos.frb.org/comaff/pdf/summer99.pdf > at 9 .

${ }^{35}$ See Nicole MacIntyre, “A Maze of Fast Cash and Fees” Toronto Star (2 November 2007), online: <http://www.thestar.com/News/article/279327>. For example, Money Mart, an "industry leader" according to the Toronto Star, charges $\$ 18.94 / \$ 100 / 1$ week; Speedy Cash charges $\$ 25$ per $\$ 100$ borrowed. See also Iain Ramsay, "Access to Credit in the Alternative Consumer Credit Market" (Paper prepared for Office of Consumer Affairs, Industry Canada, February 2000), online: < $\underline{\text { http://dsp- }}$ psd.pwgsc.gc.ca/Collection/C2-543-2000E.pdf>, though older suggests the same fees at ii.

${ }^{36}$ MacDonnell, supra note 32 at 48.

37 "What is a Payday Loan?" (Hamilton: Canadian Payday Loan Association, 2008) online: <http://www.cpla-acps.ca/english/aboutloans.php>.

${ }^{38}$ See, for example, payday loan providers like Payday Cash Advance Loans (online: $<$ http://www.paydaycashadvanceloans.biz/faq.asp $>$ ) and Speedy Cash (<online: http://www.speedycash.ca/SC-cash-advances-payday-loans-howitworks.php>).
} 
perform a credit check. ${ }^{39}$ In the case of default, practices vary, but few payday lenders will turn to litigation as the loans are for small amounts, and the likelihood of enforcing judgment against a defaulting payday borrower is low. ${ }^{40}$ Loans that cannot be recovered are written off by lenders as a bad debt expense. ${ }^{41}$ Despite the risks in the industry, in Canada, the annual profit for payday lenders in 2004 was estimated at \$1 billion. ${ }^{42}$

Between the costs of bad debt, and the overhead and other costs of running a payday lending business, the average Canadian firm incurs a cost of $\$ 20.66$ per $\$ 100$ of loans. ${ }^{43}$ However, big loan operators have lower costs than smaller "mom-and-pop" operations, and if their market share is accounted for in creating a weighted average, the average cost is only $\$ 15.69$ per $\$ 100$ loan. $^{44}$

Naturally, profits per loan are higher for repeat customers than for firsttime borrowers, as the costs of opening a new client file and verifying employment information have already been incurred. The cost of a new loan is $\$ 29.35$ per $\$ 100$ in a weighted average of payday lenders across Canada, while rollover or repeat loans only cost $\$ 14.15$ in the same study. ${ }^{45}$ This means that as stores mature and gain more repeat business, they become significantly more profitable. ${ }^{46}$

${ }^{39}$ Such as National Cash, (online: <http://www.apaydayloan.ca/ontariopaydayloan.php>) and Speedy Cash, (online: <http://www.speedycash.ca/SC-cash-advances-payday-loanshowitworks.php>).

${ }^{40}$ Ramsay, supra note 24 at 18.

${ }^{41}$ The Cost of Providing Payday Loans in Canada (Ernst \& Young: 2004) at 4 ["Ernst \& Young Report"].

${ }^{42}$ MacDonnell, supra note 32 at 49.

${ }^{43}$ Ernst \& Young Report, supra note 41 at 29.

${ }^{44}$ Ibid. at 31.

${ }^{45}$ Ibid. at 7, 34, 36.

${ }^{46}$ See ibid.; see also Chris Robinson, Regulation of Payday Lending in Canada (ACORN Canada: Vancouver, 2006), online: <http://www.acorn.org/fileadmin/Centers/Press/Report/Payday_ Lending_Canada.pdf\#search=per cent22acorn\%C20study\%C20payday\%C20lenders\%C20canada\%22>; see also James Daw, “Consumer Protection in the Wind on Payday Loans” Toronto Star (30 May 2006) at D6 (discussing the Robinson report). 
Fortunately for payday lenders, the debtors who use payday lenders are often repeat customers - Ernst \& Young estimated that first-time borrowers end up taking out an average of fifteen loans. ${ }^{47}$ This desire for repeat customers can be seen through their behaviour as many payday loan companies encourage customer loyalty; one goes as far as offering a "no fee” third loan as a bonus for customer loyalty. ${ }^{48}$

In Canada, typical borrowers are either young, single men, or young families with children, ${ }^{49}$ though other studies (commissioned by the payday lending industry) have found the average age of borrowers to range from 38 in Manitoba to 40 in British Colombia. ${ }^{50}$ They tend to be low-income, but employed, since proof of employment is required for many loans. ${ }^{51}$ Families with little savings or no credit cards, particularly those who had been refused, were significantly more likely to have used payday loans. $^{52}$

Families with outstanding bill or loan payments were more than four times as likely to have used payday loans, even after controlling for other key characteristics such as income and savings. ${ }^{53}$ Four in ten families who borrowed money through payday loans had spending that exceeded income, substantially more than families who had not used payday loans. ${ }^{54}$ Almost half of families who used payday loans had no one to turn to if

${ }^{47}$ Cited in MacDonnell, supra note 32 at 48.

${ }^{48}$ McIntyre, supra note 1.

${ }^{49}$ MacDonnell, supra note 32 at 49. The Canadian Survey of Financial Security indicates that young families were three times more likely to have used payday loans than those aged 35 to 44, after controlling for other family characteristics. See: <http://www.statcan.ca/english/freepub/75-001-XIE/10407/art-1.htm\#Kitching>. The Survey of Financial Security covered about 5,300 families and collected information on the assets and debts of families and individuals between May and July 2005.

${ }^{50}$ Payday Loan Customer Service - Manitoba (Pollara: 2007) online: Canadian Payday Loan Association <http://www.cplaacps.ca/english/reports/MB\%20Pollara\%20Poll\%20Sept\%202007.pdf> at 3, Payday Loan Customer Service - British Columbia (Pollara: 2007) online: Canadian Payday Loan Association <http:/www.cplaacps.ca/english/reports/3631\%20BC\%20CPLA\%20Report\%20FINAL\%20(Oct\%2026).p df $>$ at 3.

${ }^{51}$ MacDonnell, supra note 32 at 49.

${ }^{52}$ See $<$ http://www.statcan.ca/english/freepub/75-001-XIE/10407/art-1.htm\#Kitching >.

${ }^{53}$ Ibid.

${ }^{54}$ Ibid. 
they faced financial difficulty. ${ }^{55}$ More than one-quarter reported that they could not handle an unforeseen expenditure of $\$ 500$, and nearly half could not handle one of $\$ 5,000$. $^{56}$

Payday lenders have primarily retail store locations, "tucked in between

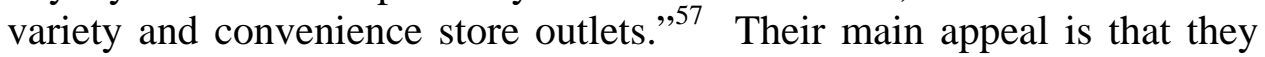
provide cash instantly, without a hold period, and that they are "nonjudgmental" and friendlier than banks; often, payday lenders will ensure they have employees who speak the language of the local community to increase their appeal. ${ }^{58}$ That these business choices make a difference to borrowers can be seen through a recent survey of payday users in Ontario conducted on behalf of the Canadian Payday Lending Association, the majority of whom stated that they used payday lenders because they are quick and easy. ${ }^{59}$

Payday lenders are not a homogenous group. There are a few larger chains, and a number of smaller providers, some of which are being acquired by national chains (and have been since 2000), ${ }^{60}$ and not every payday lender is structured the same way. There is the traditional model, where the payday loan outlet is lending its own money. There is also the broker model, where the payday lender covers the overhead costs, but is lending out a third party's money; the third party bears the risk of a loan default. Finally, in the insurance model, the lender charges a fixed fee for the loans, and an additional insurance premium charge which is designed to cover the costs of the loan and the risk of a default; the insurance company which assumes this fee is usually owned by the same payday loan operator. ${ }^{61}$

\footnotetext{
${ }^{55}$ Ibid.

${ }^{56}$ Ibid.

${ }^{57}$ MacDonnell, supra note 32 at 43.

${ }^{58}$ Ibid. at 49; Ramsay, supra note 24 at 17.

59 Payday Loan Customer Service - Ontario (Pollara: 2007) online: Canadian Payday Loan Association, <http://www.cplaacps.ca/english/reports/3631\%20Ontario\%20CPLA\%20Report\%20FINAL\%20(Oct\%202 6).pdf $>$ at 11 and 15.

${ }^{60}$ Ramsay, supra note 24 at ii.

${ }^{61}$ Ernst \& Young Report, supra note 41 at 7.
} 


\section{THE REgUlatory SCHEME GOVERNINg PAYDAY LENDERS}

\section{A. FEDERAL LEGISLATION}

The main federal legislation governing payday lenders is found in s. 347 of the Criminal Code, which prohibits entering into arrangements or receiving payment of interest at a criminal rate. ${ }^{62}$ A criminal rate is defined as any interest rate of over 60 per cent per annum; interest includes all charges and expenses, such as fees or penalties, but not official fees or overdraft charges, for example. ${ }^{63}$ However, that legislation was drafted to aid police in prosecutions of loan sharks, rather than as consumer protection legislation. ${ }^{64}$ There have been two attempts to change the status of the section federally and make it more directed towards payday lenders. The first, Bill S-19, failed due to an election. ${ }^{65}$ Bill C-26, however, came into force after receiving Royal Assent on May 3, 2007. The Bill defines payday loans as "an advancement of money in exchange for a post-dated cheque, a preauthorized debit or a future payment of a similar nature but not for any guarantee, suretyship, overdraft protection or security on property and not through a margin loan, pawnbroking, a line of credit or a credit card." 66 It then exempts payday loans for under $\$ 1500$ and for fewer than 62 days from the scope of the Criminal Code, allowing for provincial regulation of the area, if the province exercises its option to regulate under the new s. 347.1(3). ${ }^{67}$ Essentially, the province must regulate to protect payday borrowers, at which point the Governor in Council will designate the province under the section, or allow it to "opt-out."

\footnotetext{
${ }^{62}$ R.S.C. 1985 , c. C-46, s. 347(1).

${ }^{63}$ Ibid., s. 347(2).

${ }^{64}$ Mary Anne Waldron, "Section 347 of the Criminal Code: 'A Deeply Problematic Law'” (Paper presented to the Uniform Law Conference of Canada, August 2003) online: $<$ http://www.ulcc.ca/en/poam2/Section-347-Criminal-Code.pdf> at para 2-3, 11.

${ }^{65}$ Jennifer Babe, "Section 347 of the Criminal Code of Canada: Business Law Problems Remain” (Paper presented to the Uniform Law Conference of Canada, September 2007) at 4 .

${ }^{66}$ Criminal Code, supra note 23, s. 347.1(1)

${ }^{67}$ Ibid., ss. 347.1(2) and (3).
} 
Some provinces have subsequently taken steps to regulate payday lenders, though a few still have not. The provinces that have not yet attempted to regulate payday lenders are: Newfoundland and Labrador, the Northwest Territories, Nunavut, and Yukon (though there possible amendments are under review). The other provinces all have regulation, either in force or pending.

\section{B. ProvinCiAL LegisLATION}

\section{OVERVIEW}

The following is an overview of the recent provincial efforts to regulate payday lenders. The chart found in Appendix A provides a detailed comparison of the provincial regulation. Bill C-26 provides some direction as that what is required under the provincial regulation, however, it leaves room for the provinces to be designated and opt out of the federal regime with different approaches to regulation. Bill C-26 requires a licensing or other type of authorization system for lenders, the establishment of limits on the total cost of borrowing, and a framework of protections for consumers. In seeking to fit within the Bill C-26 requirements for designation, the following five components are provided for in most provinces' legislation, although there is variation among the provinces in how this is done:

a. Interest Rate Caps: Each province's regulation gives either the province, through regulation, or a body, such as the Energy Commission, the ability to set an interest rate cap. With the exception of Quebec, which has set its interest rate cap at 35 per cent, and Manitoba, which has set its interest rate cap at 17 per cent the other provinces have not yet set interest rate caps.

b. Cancellation Protection: One to two business days is provided by each province for borrower cancellation rights.

c. Information in Agreement: There is variation among the provinces. Some provinces require disclosure of the cost of 
the loan and how this is done varies. Other provinces only require a statement that the loan is a high cost loan.

d. Rollover Prohibitions: Each province prohibits rollovers or charging an additional fee for a rollover.

e. Licensing: Each province requires licensing of payday lenders and the requirements for licensing range from payment of a fee to sample loan documents. The licensor differs from province to province.

f. Posted Warning: With the exception of one province that has the ability to regulate this and has not done so and another province that does not provide for this component of the legislation, all provinces require disclosure of the cost of credit. One province requires disclosure that the indicating that the loans are high cost loans.

g. Remedies: Remedies range from an administrative penalty of up to $\$ 10,000$ to not being required to pay any amount over the principal amount borrowed.

\section{ALBERTA}

In their 2007 budget, the government of Alberta designated as one of its goals the reform of the Fair Trading Act to address marketplace issues around payday lenders. $^{68}$ It intends to regulate payday lenders through regulations passed pursuant to that Act, but it is still in consultations at this point.

\footnotetext{
68 "Budget 2007: Goal 2" (Government of Alberta: 2007) online: Ministry of Finance http://www.finance.gov.ab.ca/publications/budget/budget2007/service_ab.html.
} 


\section{BRITISH COLUMBIA}

In British Columbia, the Bill ${ }^{69}$ to regulate payday lenders was given royal assent on November 22, 2007 and amends the Business Practices and Consumer Protection (Payday Loans) Amendment Act. ${ }^{70}$ The Bill adds a Part 6.1 to the Business Practices and Consumer Act, with the title of "Payday Loans." This part allows the Lieutenant Governor in Council to set a maximum cost for payday loans and requires payday lenders to be licensed. $^{71}$ It also sets out a host of rights for payday loan consumers, including the right to cancel the loan before the end of the subsequent day or if it does not satisfy the written notice requirements; ${ }^{72}$ sets out clear disclosure requirements; ${ }^{73}$ and prohibits rollovers and second loans while loans already exist. ${ }^{74}$ Licensing and compliance enforcement will be administered by the Business Practices and Consumer Protection Authority, a not-for-profit organization that operates at arm's length from government.

\section{MANITOBA}

After the changes to the Criminal Code, Manitoba made changes to the Consumer Protection Act ${ }^{75}$ through the Consumer Protection Amendment Act (Payday Loans). ${ }^{76}$ These changes require licensing for payday lenders, and require them to give warnings to their customers about the costs of borrowing. The Act also authorizes the Manitoba Public Utility Board to set out a maximum cost of credit for payday loans, and prohibits additional fees on renewals, extensions, or new loans to replace old loans, unless otherwise authorized by the Board. The new Act also prohibits signing over of future wages and title loans, and gives the right to cancel a loan within 48 hours without penalty. Finally, the Manitoba Consumers

${ }^{69}$ Bill 27, Business Practices and Consumer Protection (Payday Loans) Amendment Act, 3d Sess., 38th Parl., British Columbia, 2007.

${ }^{70}$ S.B.C. 2004, c. 2.

${ }^{71}$ Ibid., s. 112.02.

${ }^{72}$ Ibid., s. 112.05.

${ }^{73}$ Ibid., s. 112.06.

${ }^{74}$ Ibid., s. 112.08(1)(a) and (b).

${ }^{75}$ C.C.S.M. c. C-200.

${ }^{76}$ S.M. 2006, c. 31. 
Bureau has the right to inspect licensed premises, and to access unlicensed operations if there is evidence that payday loans are being made there. ${ }^{77}$

Pursuant to the Consumer Protection Act, Manitoba has drafted the Payday Loans Regulation. ${ }^{78}$ This regulation specifies the licensing process and bonding requirements for payday lenders, and stipulates the information that must be in a loan agreement. ${ }^{79}$ It also requires payday lenders to post signs with clear warnings that "payday loans are high cost loans" and other information about the costs of payday lenders. ${ }^{80}$ Section 147(1) of the Consumer Protection also provides the Manitoba Public Utilities Board with the ability to set a limit on the costs of credit given by payday lenders. The Board set a 17 per cent interest rate cap on April 4, 2008. ${ }^{81}$

\section{NEW BRUNSWICK}

In New Brunswick, Bill 4, An Act Respecting Payday Loans, ${ }^{82}$ passed the second reading as of December 12, 2007. Like the other provinces, the Bill is designed to protect payday borrowers through licensing and bonding requirements for payday lenders, ${ }^{83}$ informational requirements on the payday loan itself (including all fees and penalties charged), ${ }^{84}$ no-fee cancellation options, ${ }^{85}$ posted information about the cost of loans, ${ }^{86}$ and it grants the government the ability to limit the cost of credit. $^{87}$

\footnotetext{
77 “Province Announces Next Steps in Payday Loan Regulation” online: Government of Manitoba, <http://news.gov.mb.ca/news/index.html?archive=2007-6-01\&item=1751 >.

${ }^{78}$ Man. Reg. 99/2007.

${ }^{79}$ Ibid., s. 14.

${ }^{80}$ Ibid., s. 16(3).

${ }^{81}$ Consumer Protection Act, supra note 75, Part XVIII. The interest rate cap was introduced by the Manitoba Public Utilities Board Act Order 39/08 online: http://www.pub.gov.mb.ca/pdf/misc/39-08.pdf.

82 2d Sess., 56 ${ }^{\text {th }}$ Parl., New Brunswick, 2007. This Bill will amend the Cost of Credit Disclosure Act, R.S.N.B. 1973, c. C-28.3.

${ }^{83}$ Ibid., ss. 37.12; 37.15.

${ }^{84}$ Ibid., ss. 37.28(2)(m).

${ }^{85}$ Ibid., s. 37.29.

${ }^{86}$ Ibid., s. 37.3.

${ }^{87}$ Ibid., s. 37.31.
} 


\section{NOVA SCOTIA}

The Nova Scotia Utility and Review Board is currently in consultations to determine the limits to be set on payday lending. To that end, they held public hearings in January 2008 to consider preliminary issues including the maximum cost of borrowing and the maximum fees or rates that could be charged by payday lenders. ${ }^{88}$

The authority to embark on these consultations was granted by the Consumer Protection Act (amended), which received Royal Assent on November 23, 2006. ${ }^{89}$ Sections 18A-18U of that Act provide for similar protections to all other provinces. There is a permit requirement for payday lenders, ${ }^{90}$ informational requirements in the loan agreement, ${ }^{91}$ and cancellation provisions. ${ }^{92}$ The Act also grants the Nova Scotia Utilities and Review Board the ability to set a maximum cost of borrowing and other controls. $^{93}$

\section{ONTARIO}

In Ontario, amendments to the Consumer Protection Act, 2002 requiring greater disclosure by payday lenders are already in effect. They pertain to the posting of a disclosure poster that must indicate certain pieces of information. For instance, payday lenders must display the cost per hundred dollars of the loans they grant. They also require that payday lenders display the cost of a " $\$ 300$ loan over a period of 14 days." Further changes also require a standard form for payday loans which will also provide greater information to the consumer. ${ }^{95}$

\footnotetext{
${ }^{88}$ Nova Scotia Utilities Review Board, "Payday Loans, Notice of Public Hearings" online: Canadian Payday Loan Association <http://www.cplaacps.ca/english/reports/NS\%20-Payday_Loans_Notice.pdf>.

${ }^{89}$ S.N.S., 2006, c. 25.

${ }^{90}$ Ibid., ss. 18C-G.

${ }^{91}$ Ibid., ss. 18I-N.

${ }^{92}$ Ibid., s. 18Q.

${ }^{93}$ Ibid., s. 18T.

${ }^{94}$ O. Reg. $17 / 05$ as am by O. Reg. 187/07 61.1. According to 61.1 there is no requirement to have the APR disclosed on the poster, the only requirement is that it is disclosed in the loan agreement itself.

${ }^{95}$ Ibid., s. 62.1.
} 
Most recently, on March 31, 2008 the Government announced Bill 48: Payday Loans Act, ${ }^{96}$ which will be in addition to the provisions in the Consumer Protection Act, 2002. It requires all payday lenders and brokers to be licensed and establishes a Registrar to inspect lenders and enforce provisions under the Act. ${ }^{97}$ The Act seeks to protect borrowers by prohibiting lenders from making misleading claims about the total cost of borrowing. ${ }^{98}$ It also provides for a two-day cancellation period where the borrower can cancel the loan agreement and pay back the advance. ${ }^{99}$ The lender is forced to return all documents and fees pertaining to the cost of borrowing, without penalty. The Act also provides for very broad regulations pertaining to the specific responsibilities of licensees, governing their activities, setting limits that payday lenders and brokers may charge and governing the required contents for payday loan agreements. $^{100}$ Remedies include: a rebate on the cost of borrowing for borrowers who entered into agreements not consistent with the Act, freezing of assets of delinquent lenders, ${ }^{101}$ and the imposition of administrative penalties not exceeding $\$ 10,000 .^{102}$

Finally, the Act established a special fund, known as the Ontario Payday Lending Education Fund (OPLEF), to educate borrowers about their rights under the Act. ${ }^{103}$ The OPLEF will be a non-profit corporation and will be funded in part by the payday lenders and brokers. The OPLEF is required to report on its activities and administration through an annual report to the Minister who will then deposit the report with the Assembly. ${ }^{104}$ Ontario is the only province to include an educational component in its legislation.

\footnotetext{
${ }^{96}$ Bill 48, Payday Loans Act, 1st Sess., 39th Parl., Ontario, 2008 (first reading on March 31, 2008).

${ }^{97}$ Ibid., s. 5.

${ }^{98}$ Ibid., s. 26(1).

${ }^{99}$ Ibid., s. 30(1).

${ }^{100}$ Ibid., s. 77.

${ }^{101}$ Ibid., s. 52(1).

${ }^{102}$ Ibid., s. 59(1)-(3).

${ }^{103}$ Ibid., s. 66-67.

${ }^{104}$ Ibid., s. 74.
} 
The Minister hailed the new legislation as an attempt to balance protecting consumers while supporting a legitimate industry to continue to grow. ${ }^{105}$ When pressed on why the legislation does not contain a clear unambiguous interest rate cap, the Minister said more information was required. He established an independent expert panel, representing business and poverty activists, to examine the rate cap and report at a later date. $^{106}$

A number of Members of Parliament, such as Andrea Horwath, have already criticized the Bill as not going far enough to protect consumers. ${ }^{107}$ She believes that an interest rate cap should be clearly included in the Bill as well as a 30 day "cooling-off" period for rescission. ${ }^{108}$ Another Member of Parliament, Cheri DiNovo, states that "We don't need payday lenders. Payday lenders are usurious. These are unnecessary services and they leech off the poor." ${ }^{109}$ Howard Hampton, leader of the provincial NDP Party, called the legislation superficial and criticized the government as being "scared" to put the payday loan industry out-of-business with an interest rate cap. ${ }^{110}$

Representatives from ACORN Canada (Association of Community Organizations for Reform Now) again stressed the importance of an interest rate cap- "It's either going to protect people and keep money from getting sucked out of low-income neighbourhoods or not, depending on what the interest rate is."111 Other poverty activists stressed the need for education that would actually find its way to the most vulnerable consumers. ${ }^{112}$ They recommend starting education campaigns in payday locations or through different anti-poverty groups. However, poverty

\footnotetext{
${ }^{105}$ Interview of Government Services Minister Ted McMeekin, (1 April 2008) on Metro Morning, CBC Radio, Toronto, CBC Radio Archives.

${ }^{106}$ Ibid.

107 First Reading of Bill 48, Debates and Proceedings, March 31, 2008 $<$ http://www.ontla.on.ca/web/house-proceedings/house detail.do?Date=2008-0331\&Parl=39\&Sess $=1 \&$ locale $=$ en\#PARA139> .

$\frac{108}{108 i d .}$

109 Joanna Smith and Robert Benzie, "Payday loan crackdown” Toronto Star (April 1, 2008), online: The Star $<$ http://www.thestar.com/News/Ontario/article/407813 $>$.

${ }^{110}$ Supra note 16.

${ }^{111}$ Supra note 20.

112 Interview of Miryam Zeballos, (1 April 2008) on Metro Morning, CBC Radio, Toronto, CBC Radio Archives.
} 
activists were quick to note that the education can only go so far when consumers are also placed with crushing time-pressures in paying back the loan within several days. ${ }^{113}$ The Canadian Payday Loan Association ("CPLA") remains silent on the new legislation, as of April 1, 2008. However, in an interview CPLA President Stan Keyes, applauded the Bill as a right balance. ${ }^{114}$ Keyes refused to comment on an "interest rate cap based on APR", calling it a meaningless number. ${ }^{115}$ However, he does support the use of fee caps of between $\$ 20-23$ per $\$ 100$ loan. ${ }^{116}$

\section{PRINCE EDWARD ISLAND}

PEI's Bill 100, Payday Loans Act, has not yet moved past the first reading, which occurred in the spring 2006 legislative session. ${ }^{117}$ However, if passed, the Bill will implement many of the same changes seen in the other provinces, including licensing, ${ }^{118}$ maximum cost of credit, ${ }^{119}$ getting appropriate information to the consumer, ${ }^{120}$ and penalty-free cancellation within the first 48 hours. ${ }^{121}$

\section{QUEBEC}

Quebec's Consumer Protection Act requires that a lender have a license to operate there, and courts have decided to only grant licenses if creditor charges less than 35 per cent interest rate, because the loan is otherwise unconscionable under s. 8 and so can be denied under s. $325 .{ }^{122}$ There are no payday lenders legally operating in Quebec. ${ }^{123}$

\footnotetext{
113 Ibid.

${ }^{114}$ Supra note 16.

115 Ibid.

${ }^{116}$ Ibid.

${ }_{117} 4^{\text {th }}$ Sess., $62^{\text {nd }}$ Parl., Prince Edward Island, 2007.

${ }^{118}$ Ibid., s. 10.

${ }^{119}$ Ibid., s. 11.

${ }^{120}$ Ibid., s. 12.

${ }^{121}$ Ibid., s. 13.

122 R.S.Q., c. P-40.1, ss. 8, 325.

${ }^{123}$ Government of Ontario, "New Payday Lending Rules Now in Effect Across Ontario" online: Ministry of Government and Consumer Services
} 


\section{SASKATCHEWAN}

Like the other provinces that have sought to regulate payday lenders, Saskatchewan provides similar protections to borrowers in the province. An Act Respecting Payday Loan Agreements, Payday Lenders and Borrowers received royal assent and came into effect in May 2007. ${ }^{124}$ It has licensing requirements for lenders, ${ }^{125}$ disclosure requirements for the protection of borrowers through public signage ${ }^{126}$ and the credit agreement, ${ }^{127}$ and allows the province to set a maximum rate for credit. ${ }^{128}$ However, again, the maximum has not yet been set by regulation.

\section{SELF-REgulation By PAydAy LENDERS}

The CPLA is the largest Canadian association of payday lenders, and claims to represent 500 of the 1350 payday lending stores in Canada. ${ }^{129}$ It claims that its Code of Best Business Practices ("Code") is recognized as the "world's toughest voluntary code of conduct," and it has recently set up a Commissioner of Ethics and Integrity, whose job it is to independently enforce the practices in the Code. ${ }^{130}$

The Code, first and foremost, prohibits rollover loans, which are widely decried by industry critics. ${ }^{131}$ In doing so, it specifically bars members

<http://ogov.newswire.ca/ontario/GPOE/2007/08/01/c2939.html?lmatch=\&lang=_e.html

$>$.

124 2007, c. P-4.3.

${ }^{125}$ Ibid., Part II.

${ }^{126}$ Ibid., s. 21.

${ }^{127}$ Ibid., s. 18.

${ }^{128}$ Ibid., s. 23.

129 Office of the Ethics and Integrity Commissioner, “Annual Report 2006-2007” (Canadian Payday Loan Association: Hamilton, 2008) online: $<$ http://www.cplaethicscommissioner.ca/english/pdf/OEIC_CPLA_AnnualReport_0607.p df> [“Annual Report”].

$\frac{\mathrm{d}}{130}$ "Canadian Payday Loan Association Appoints Former Law Enforcement Official Sid Peckford Ethics and Integrity Commissioner" (RTO Online: 2006) online: $<$ http://www.rtoonline.com/Content/Article/May06/CanadianPaydayLoanAssociationAp pointsPickfordEthics050406.asp>.

131 "Code of Best Business Practices" (Canadian Payday Loan Association: Hamilton, 2008) online: <http://www.cpla-acps.ca/english/consumercode.php>. Recall that in most 
from granting loan extensions for a fee, or from advancing a new loan to pay down an existing loan. The Code also prohibits multiple loans in excess of the initial amount the lender was approved for, and prevents lenders from taking collateral. Further, it sets a limit on the amount a member may charge on the default of the loan, and only allows lenders to charge post-maturity interest at a rate of $\$ 0.90 /$ week for the first 13 weeks, and $\$ 0.50$ per week thereafter.

Members are also required to recommend credit counseling to any customer who has defaulted twice within a year, and offer to forego accrual of interest for customers who do go into counseling. There are also restrictions on the type of loans that a member may offer - a member may not give a loan based on some social assistance payments or take an assignment of wages, neither may they grant a loan over $\$ 1500$ or a loan for a term of over 31 days.

The Code also has similar requirements to many of the provinces' proposed or enacted legislation, in allowing no-penalty cancellation of the loan if done by the end of the next business day. It also stipulates that the member should disclose to the customer the "high-cost nature of the payday loan on all loan documentation."132 Notably, however, the one area that the Code does not touch on is the amount that can be charged in fees and interest (until maturity) on loans.

This Code is enforced by the Office of Ethics and Integrity Commissioner, a position funded by CPLA but designed to operate independently. ${ }^{133}$ Any complaints about a violation of the Code are made via a 1-800 number staffed by a full time Compliance Officer who will determine which prospective violations require further action, and will make submissions with recommendations on each violation for the Commissioner. The Commissioner then has the mandate to investigate and follow-up on any violations brought to his attention; he also has the ability to issue

"horror stories" about payday loans in the press, the journalist will give the example of a person who got a rollover loan and ended up making payments for months without paying down the initial loan because the loan was rolled over.

${ }^{132}$ Ibid.

133 "About the Office of the Ethics and Integrity Commissioner" (Canadian Payday Loan Association: Hamilton, 2008)

$<$ http://www.cplaethicscommissioner.ca/english/about.html>. 
warnings, or fine or otherwise discipline members who have not complied with the Code. In 2007, 164 complaints were made via the 1-800 number or email; 87 were deemed to merit further investigation; in 16 cases the Commissioner concluded a violation occurred; 10 members were sanctioned and the other 6 responded with a "satisfactory resolution" to the matter. ${ }^{134}$

\section{Calling on Canadian Payday Lenders}

On March 22 and March 28, 2008, a female student research assistant, along with a male research partner visited 4 different payday lenders in downtown Toronto. In two cases, two locations of the payday lender where visited, totaling 6 visits. The research assistant who conducted the visits is a third year Osgoode Hall Law School student who is white, in her mid-twenties, has worked with the author on payday lending research for over three months, and has seven years of post-secondary education. Her male friend, a third year medical student, is also white and in his midtwenties.

The instruction provided to the student was to obtain all the information that she could about how much it would cost to obtain a payday loan and what she was required to do in order to obtain the loan. The student has asked that her identity is kept anonymous as she is joining a law firm upon graduation from law school that represents a major player in the payday lending industry.

\section{A. ONTARIO Disclosure REQUIREMENTS FOR PAYDAY LENDERS}

Section 61.1(4) of the Consumer Protection Act requires the following statements:

1. Total Cost of Borrowing per each $\$ 100$ as heading (larger font)

2. Subheading indicating “\$300 loan for 14 days” (smaller font)

\footnotetext{
${ }^{134}$ Annual Report, supra note 129 at 7.
} 
3. "Principal Amount \$300.00" AND "Total Cost of Borrowing" followed by the total cost of borrowing per each $\$ 300$ advanced under the agreement

4. Horizontal line

5. "Total to Repay"

6. "This sign conforms to the disclosure requirements under the CPA”

The visits to the payday lenders indicated that most of the required terms were provided as per statutory requirements, however, payday lenders' interpretation of the terms varied widely. The following table highlights the difficulty in trying to ascertain how much each loan cost and to compare the cost of borrowing as between the different lenders.

$\underline{\text { Table } 1}$

\begin{tabular}{|c|c|c|c|c|}
\hline $\begin{array}{l}\text { Disclosure } \\
\text { Requirements }\end{array}$ & Money Mart & Cash Money & Cash Shop & Cash Store \\
\hline $\begin{array}{l}\text { Total Cost of } \\
\text { Borrowing per } \\
\$ 100 \\
\text { (larger font) }\end{array}$ & $\begin{array}{l}\$ 1.78 \text { and } \$ 19.45 \\
\text { with optional } \\
\text { cheque cashing fees }\end{array}$ & $\$ 20.00$ & $\$ 20.00$ & $\begin{array}{l}\$ 22.26 \\
*(\$ 100 \text { includes a } \$ 20 \\
\text { broker fee })\end{array}$ \\
\hline $\begin{array}{l}\text { "Example: } \$ 300 \\
\text { loan for } 14 \text { days" } \\
\text { (smaller font) }\end{array}$ & $\begin{array}{l}\text { No number } \\
\text { included. }\end{array}$ & $\$ 60.00$ & $\begin{array}{l}\text { No number } \\
\text { included. }\end{array}$ & No number included. \\
\hline $\begin{array}{l}\text { "Principal } \\
\text { Amount" }\end{array}$ & $\$ 300.00$ & $\$ 300.00$ & $\$ 300.00$ & $\$ 300.00$ \\
\hline $\begin{array}{l}\text { "Total Cost of } \\
\text { Borrowing" }\end{array}$ & $\$ 5.34$ & $\begin{array}{l}\$ 20.00 \text { per } \$ 100 \\
\text { borrowed } \\
\$ 60.00 \text { per } \$ 300 \\
\text { borrowed }\end{array}$ & $\$ 60.00$ & $\$ 66.79$ \\
\hline "Total to Repay" & $\$ 305.34$ & $\$ 360.00$ & $\$ 360.00$ & $\begin{array}{l}\$ 306.79 \\
* \text { Does not reflect the } \\
\text { net amount received; } \\
\text { reflects the gross } \\
\text { amount borrowed. }\end{array}$ \\
\hline $\begin{array}{l}\text { "This sign } \\
\text { conforms to the } \\
\text { disclosure } \\
\text { requirements } \\
\text { under the CPA" }\end{array}$ & Included. & Included. & Included. & Included. \\
\hline
\end{tabular}

* This statement is printed on the Cash Store's Disclosure Poster 


\section{B. Visits TO 6 TORONTO PAYDAY LENDERS}

At each location, the student asked the following five questions. The responses below are in her language. She relied on her research partner to aid with data collection. He would enter the store after she had left (or as she was leaving) and collect any promotional material they might have had. After her departure from two of the six locations, the store employee commented, without prompting, to the rest of individuals in the store on 'how many questions' she had asked, and that it was 'funny' for her to want to write things down. These statements clearly indicate that the student's haphazard way of collecting information was, in comparison to other payday borrowers, quite exceptional.

\section{What is a payday loan?}

Most operators replied that a payday loan is a short-term loan. They would provide me with a certain amount of money, which I am expected to pay back on my next payday. This was usually about 10 days, but could be extended or reduced depending on the next time I would get paid.

\section{What do I need to provide to qualify for a payday loan?}

The following documents were required for me to apply for a loan. But, it was not a guarantee of whether or not I'd be accepted. The employees assured me that qualifying would take less then 10 minutes. But when I asked what the process would involve (ie. calling employers etc...) they didn't answer but instead refocused my attention on how fast it would be.

Money Mart: A current bank statement; latest pay stub; postdated personal cheque

Cash Money: Pay stub; personal cheque; bank statement (from today or the day before). 
Cash Shop: Proof of continuous employment at the same job for six months; get paid through direct deposit; no more then 1 Non Sufficient Fund fee in the past 2 months; 2 pay stubs; 2 pieces of ID; A utility/phone bill; an updated bank statement for the last 45 days

Cash Store: a current bank statement; latest pay stub; personal cheque; utility bill; personal references (family members who had landlines were preferred).

\section{What is the most money I could get?}

All locations began by stipulating that I could get approved for up to $50 \%$ of my net salary. Cash Shop said that since "I looked ok" they would be able to go up to 70\%. Cash Money also said that they could go up to 70\% for repeat customers who had a 'positive relationship' with Cash Money.

\section{How much does it cost to borrow?}

Each employee pointed to the poster and proceeded to read the poster to me. When I asked specifically what the terms 'cost of borrowing' and 'total to repay' meant, they declined to answer.

The Term 'Total Cost of Borrowing' varies widely from \$5.34 and $\$ 66.79$. Furthermore Cash Money's use of the term is confusing by stating the \$20.00 first, even though the example asks for the \$300 example ... which would then be $\$ 60.00$.

The term 'Total to Repay' is also widely misinterpreted. You can see that Cash Money and Cash Shop are relatively straightforward, the consumer should repay $\$ 360.00$ and one could assume that would be the total written on my post-dated cheque or direct transfer form. However, Money Mart and Cash Store indicate substantially lower levels of 'Total to Repay'. But these totals do not include the brokerage and optional cheque cashing fees, which are in most cases mandatory charges. 
At Cash Store, I was told that the brokerage fees were mandatory, and were due to the fact that the Cash Store 'linked, me, the borrower with an independent lender'. Cash Store did not actually lend me the money themselves. I still do not know what total I would be required to write on my post-dated cheque.

The optional cheque cashing fees employed by Money Mart were the most confusing. All their advertising indicates that they charge 59\% interest, or about 90 cents/week per 100 dollar loan. However the advertising also seems to indicate that there is an 'optional' cheque cashing fee. Upon prompting, the store employee told me that if I paid back the loan in full on the loan due date (the day before my payday) I would pay the advertised rates. However, if I waited until payday, Money Mart would cash my cheque and charge an extra $\$ 19.95$ per 100 dollars. This was seen as a convenience fee, and the employee stressed this was optional ... kind of like valet parking. However, I find it very difficult to believe how someone who has limited income, and took out a loan in the first place, would then be able to pay it off BEFORE the receive their regular salary. Thus the vast majority of borrowers are forced to pay this convenience fee.

I'm also concerned with the widespread use of the word 'AND' as opposed to 'PLUS'. While it's a small change (and not illegal) I don't think it conveys to the consumer that they are also responsible for this charge.

\section{Can I get a copy of the information?}

Once they began providing details, I would ask if they had any information written down. They usually had written information pertaining to the materials I needed to bring in to qualify for a loan. However, none of the information about prices was written down, although they did let me copy the information on the poster down by hand when I prompted. I clandestinely took the photos with my cell phone.

I was able to get two loan applications. On Cash Shop's application there appears to be a statement about wage 
assignment-which is not legal in Ontario. [Pursuant to The Wages Act, 1990, payday lenders are prohibited from taking wage assignments under Subsection 7 (7), which states that an assignment of wages to secure payment of a debt is invalid. In addition, a representation that such assignments are valid may be considered a false, misleading or deceptive representation under the Consumer Protection Act, 2002.]

\section{What if I can't pay the loan back?}

On both the Cash Store and Money Mart's website it clearly says that no rollovers are permitted.

The Cash Shop indicated that if I couldn't pay off the loan that they would be able renegotiate something with me. Cash Store also said that I must pay off the loan, but if I thought that there was no other way ... then I was supposed to come into the store and talk to them before my next payday.

Cash Money also indicated that I would have to pay off the loan on my next payday. But if I was in dire circumstances they would wait one or two days before cashing the cheque. The Cash Money employee also said that I should consider using the 'pick up' option to pay off my loan. If I come in on my payday (not the day before) and pay my loan in full, in cash, then they would immediately loan me the same amount of my previous loan. This, she indicated, was considered a new loan and I would have to pay new fees associated with taking out a loan. The Cash Money employee said the vast majority of individuals preferred the pickup option.

I thought it was rather odd that people would want to go through the trouble of going to the payday loan, rather then letting the cheque clear, since at Cash Money there is no cheque cashing convenience fee. In other words, it would cost the same to pick up the loan or to let the cheque clear. She said that if individuals waiting 2 or 3 days for the cheque to clear, they would not be able to take out another loan (since borrowers are only allowed one loan at a time). With the pick-up option, they could take out the 
new loan on the same day. One could assume therefore, that not only is this pick-up option a rollover, but that the majority of borrowers rely upon them.

Even Money Mart, who prohibits rollovers under the CPLA Best Practices, stated I could apply for a 'back-to-back' loan. If I had enough funds to clear the first cheque, Money Mart would immediately loan me the exact amount that was just cleared from my account. While not technically a rollover, the risk of debt spiral would still be present-as I would never have enough money to clear the loan and provide for myself for the next two weeks. Money Mart would also receive new fees from my 'back-toback' loan every two weeks. For example, if I pursued 'back-toback' loans for one year (26 loans) on a principal amount of \$300 I would pay roughly $\$ 60$ in interest every two weeks. In this case, Money Mart would receive over $\$ 1,560$ in interest (520\% APR), for a $\$ 300$ loan.

The student reports the following conclusion regarding her experience in attempting to get a payday loan and the relevant information:

I found it very difficult to determine how much the loan would ultimately cost me. I am therefore quite adamant in saying that the average payday loan consumer may not know how much they are paying for their loan when they sign the agreement, nor are they fully capable of "shopping around' to find the best deal.

I am even more convinced of my conclusion when one thinks that all payday loan borrowers, through the act of looking for a loan, are already under financial stress and will not be in the more contemplative state-of-mind I was experiencing. (i.e. I didn't actually need the loan to pay for groceries, facing the risk of eviction etc...) The stress of 'getting the money now' would drastically impair one's ability to effectively compute the highly complicated and intentionally confusing information associated with payday loans. 


\section{AMERICAN REGULATORY LESSONS}

In contrast to the more mature American payday lending industry, and accompanying attempts at regulation, the Canadian payday lending industry is new and until fairly recently has been unregulated. Accordingly, this section reviews the dominant American approaches taken to regulate payday lenders with a view to drawing regulatory lessons for the Canadian context.

\section{A. DisClOSURE}

The provincial regulation requires disclosure in the form of posted warnings and information in agreements about the cost of credit and the high cost of the loans. Commentators reflecting on the American experience with disclosure as a tool for limiting predatory practices used by payday lenders suggest that disclosure should be made in the form of clear costs of borrowing rather than APR. That is, it should be clearly stated that a loan will cost, for example, $\$ 20$ for $\$ 100$ borrowed for one week, totaling $\$ 120$ for one week. Any additional fees should also be clearly noted. The total cost should be posted clearly at the front of the store or on the counter in a similar fashion to the way that banks post the daily exchange rate. In addition, the posted notice should clearly indicate that these loans are intended to be short-term. The Ontario legislation, like the other proposed and proclaimed provincial legislation, attempts to provide for this information, however, as was evidenced by the on-site visits, the variation in the way that this information was provided made it difficult to understand and also difficult to compare among stores.

Doubt is cast on the potential of disclosure as a regulatory tool by the research on bounded rationality that suggests that consumers do not always act in the rational way that underlies the rationale for disclosure. ${ }^{135}$ As is highlighted by the research on the American experience with disclosure regulation, various other factors, such as convenience and sunk search costs, may limit the utility of disclosure. ${ }^{136}$ On the other hand, the

\footnotetext{
${ }^{135}$ Ramsay, supra note 24 at 30.

${ }^{136}$ Ibid.
} 
provision of comparative price and term information by a neutral third party has been put forward as the most effective form of disclosure. ${ }^{137}$ None of the current provincial regulatory schemes or proposals provide for this relatively low-cost measure.

\section{B. LICENSING}

Licensing of payday lenders by third party provincially regulated bodies holds the potential to address the issues surrounding the utility of disclosure. In addition to serving a gatekeeping function, such bodies are in a position to provide an effective form of information disclosure, including comparative information. To assist customers with shopping around prior to visiting a payday lender, licensees should be required to provide daily reports of fees to the licensor, who should in turn make these available to potential borrowers on the internet or through other means. Further, on-site visits from provincial regulators may deter lenders from making oral representations that contradict posted disclosure, disclosure in agreements, or provincial legislation. The on-site visits to the Toronto payday lenders illustrate that large operators are violating the selfregulatory standards they helped craft surrounding rollovers, for example.

The funding for on-site visits would come from licensing costs paid by the payday lenders. The challenge will be for the licensing body to resist becoming "captured" by the payday lending industry. This concern should be factored into decisions surrounding the appropriate licensing framework. That is, whether the licensor should be within the provincial consumer affairs ministry or a delegated administrative authority where an arm's length agency administers the regime. The provinces where there is a public utility commission or board appear to have delegated authority to these semi autonomous provincially regulated bodies. The other provinces appear to have taken the former approach.

${ }^{137}$ Ibid. 


\section{ROLLOVERS}

Each province that has put forward regulation has prohibited rollovers or charging an additional fee for a rollover. This prohibition is also found in the industry's self-regulation. Given that rollovers are a clearly a regular practice associated with the business model for payday lenders operating in Canada, and that the existing prohibition imposed by payday lenders' self-regulatory body is ignored by lenders, a different approach is necessary. It may be more reasonable to regulate the conditions for a rollover to take place and to require disclosure of not only the cost of the loan but also the cost of a rollover. In addition, a cap may be set on the number of times a rollover may be permitted and posted warnings about the high cost of rollovers may be considered.

\section{ENFORCEMENT}

While class actions have entered the scene as an attempt to use the judicial system to obtain a remedy for usurious interest rates charged by payday lenders, the results remain to be seen. Class actions aside, most low income borrowers will not have the resources to take action in court against payday lenders. Accordingly, the most effective method for enforcing the requirements in the new legislation is a simple vehicle for complaint to the licensor that will result in non-recovery of the loan amount by the lender. A number of the proposed or existing provincial regimes merely provide that the interest will not be recoverable if the legislation is violated. This is an insufficient form of deterrence; the principle and interest should not be repayable. Detailed statistics should be kept on all on-site visits, complaints, and resolutions.

\section{E. EDUCATION AND COUNSELING}

In contrast to some American states counselling has not been adopted as part of the provincial regulatory models. While there has been much criticism regarding the counselling requirement for bankruptcy in Canada, it may be a helpful tool, when used in conjunction with the other tools discussed, in this context. Potential borrowers should be required to 
participate in counseling session prior to taking a second payday loan in a set period of time or attempting to rollover a payday loan. Such sessions may be provided online for literate consumers or in person and should be financed through the payday lenders, but provided by the government through the licensing body or another delegated authority. The counseling cost should not be passed on to potential borrowers.

The main criticism leveled against counseling in the bankruptcy context is that it adopts a "blame the victim" approach and focuses on helping the debtor adopt better financial management practices. While in some instances instruction on better budgeting practices may be helpful, often low income debtors will simply not have the money available to budget with. It would be more useful to outline the borrower's rights with respect to their outstanding payday loans. For example, the fact that it is not cost effective for payday lenders to commence an action against a borrower for an unpaid loan, may be helpful information to a debtor contemplating her options. In addition, a detailed explanation of the costs associated with rolling over a loan and exploration of other possible sources of longer term credit may be helpful.

Consideration should also be given to introducing some form of financial education into the high school curriculum or even college and university level curriculum. In addition, public education sessions financed by the licensing fees paid by payday lenders and held by licensors would be helpful. The OPLEF provided for under the new Ontario legislation provides a model for this approach. The implementation of either form of education should not be used to justify limiting other measures such as disclosure or interest rate caps.

\section{F. INTEREST RATE CAPS}

As increased regulatory measures are imposed on payday lenders they will undoubtedly argue that these measures will drive them out of business. The democratization of credit that payday lenders have helped facilitate is not in itself a bad thing and should not be treated as such. The Quebec experience, where registration and a maximum interest cap of 35 per cent are in place, and where there are no payday lenders operating in the 
jurisdiction may be used to illustrate the impact that regulatory decisions may have on the continued viability of the industry. However, it is important to highlight that Credit Unions have played a much more prevalent role in the Quebec alternative credit market, and accordingly, interest rate caps are not a complete explanation. ${ }^{138}$ Further, the American experience suggests that payday lenders can adapt their business model to a regulated lending environment with interest rate caps. In implementing interest rate caps, it will be important to follow Ramsay's line of reasoning, "there is probably a convincing argument that may be made for using interest rate ceilings as a method of protecting against excessive rates but not as a means of second guessing market rates." Market rates in this context need to account for the current practice of not performing credit checks or detailed assessments of ability to pay prior to providing payday loans to borrowers in Canada. Introducing such practices in this market will limit access to credit for groups of borrowers that are otherwise excluded from accessing credit and potentially push them into even more expensive and unregulated arenas.

To date, other than Quebec, only Manitoba has settled on an interest rate cap. A formula that attaches both to the changing markets and limits on excessive rates will need to be developed as the other provinces move forward. Consultation on appropriate rates should not be limited to the lenders or financial experts, but should also include poverty experts and payday loan consumers.

\section{G. Provincial HaRmonization}

The Uniform Law Conference of Canada appears to have given limited attention to the issue of payday lenders following the amendment to the

138 Ibid. at 37. Given that the Federal government has exclusive jurisdiction over banking, interests and negotiable instruments and the provinces over property and civil rights, there may be a constitutional issue related to the provinces setting interest rate caps. However, as Mary Anne Waldron has concluded, "while the Federal government was given the exclusive power to legislate on interest in the constitution, the provincial legislatures have been permitted by the courts to care out a significant and, perhaps widening sphere of jurisdiction.” M. Waldron, The Law of Interest in Canada (Caswell: 1992) at 28, as cited in Ramsay supra note 24 at 27. 
Criminal Code giving the provinces the ability to regulate in this area. ${ }^{139}$ The Consumer Measures Committee (CMC), a federal-provincialterritorial intergovernmental working group that seeks national approaches to consumer protection issues has also give the issue limited consideration. ${ }^{140}$ Ontario's Ministry of Government Services Policy and Consumer Protection Services Division indicates that it's “preference is for a harmonized national approach to regulation and interest rate setting, with a federal lead on rate setting to create a national standard for the industry."141 However, to date an analysis and recommendations surrounding the harmonization of payday lending legislation has not been provided and multiple provincial attempts at reform appear to be simultaneously proceeding without an attempt at national consultation. Ramsay provided a Model Act with his report in 2000, however, a harmonized approach has not been adopted by the provinces. It continues to be true that vulnerable consumers' interests and needs with respect to payday lenders do not vary from jurisdiction to jurisdiction so as to justify the variation in existing and proposed legislation in this area continue, ${ }^{142}$ however, there remains no Canadian experience to justify choosing one regulatory approach over another.

Ultimately an effort should be made to work towards a Model Act. However, at this early stage in seeking to regulate a previously unregulated industry variation in provincial regulation may be a useful way to assess the effectiveness of various approaches to regulating the industry. In addition, future work will need to consider the limits of domestic regulation of payday lenders and the extent to which the internet and other technologies are facilitating payday lending across provincial and national borders.

\footnotetext{
${ }^{139}$ Babe, supra note 65.

140 “Alternative Consumer Credit - Working Group” online: Consumer Measures Committee <http://cmcweb.ca/epic/site/cmc-cmc.nsf/en/fe00025e.html>.

141 Consumer Protection in the Payday Lending Sector (April 27, 2007) online: <http://www.gov.on.ca/mgs/graphics/126614.pdf>.

${ }^{142}$ Ramsay, supra note 24 at 27.
} 


\section{CONCLUSION}

This article has focused on assessing the evolving Canadian payday lending regulatory framework as a discrete area of regulation of overindebtness of low income Canadians. A detailed assessment and comparison of the regulation of other forms of credit in the alternative credit market was beyond the scope of the current project. The ability and the willingness of the provinces to regulate payday loans following Bill C26 provide a unique opening. The development of ex-ante regulation that will at the same time continue to grant low-income Canadians access to credit through payday loans and protect them from predatory practices, provides an occasion to reflect on best practices for regulating overindebtness of lower income Canadians. Up until this point, for the most part, only middle-class Canadians had access to expansive regulation and relief from overindebtness through the bankruptcy regime. While an increasing number of low-income Canadians now have access to credit, they continue to have limited access to the bankruptcy regime. Apart from measures aimed at increasing access to this ex-post remedy, the current process of providing ex-ante relief is also promising. In order to make this form of regulation meaningful lessons from the American experience should be taken seriously and regulation that is helpful to the actual consumers of payday loans should be carefully developed. An ongoing effort should be undertaken to evaluate and compare provincial efforts at regulation with a view to developing a domestic, and possibly in the future, international model payday lending legislation.

The provincial reform efforts may contribute to the development of a heightened sense of corporate social responsibility on the part of payday lenders, which may in turn also facilitate a change in their lending practices. As the payday lending industry expands in Canada, an increasing number of payday loans are offered by publicly traded corporations that are accountable to an increasing number of shareholders and other corporate stakeholders. Future research should consider the role of Canadian corporate and securities law in facilitating a change in the corporate governance practices of payday lenders. In addition, further research is necessary on the role of regulation and governance practices in ensuring that mainstream financial institutions operate in a socially responsible way in relation to lower income debtors. 
Canadian banks, like their American counterparts, have been quite reluctant to deal with low-income borrowers in a more direct fashion. They risk criticism if they reject too many customers, or charge higher interests rates or use remedies such as foreclosure. ${ }^{143}$ Therefore, there is a tendency for larger financial institutions to just avoid an area, making it very attractive to predatory lenders. This practice dates back to the middle of the twentieth century when many American banks discriminated against certain racialized neighbourhoods through the practice of redlining. ${ }^{144}$ As a result, Congress enacted the Community Reinvestment Act (CRA) to mandate financial institutions "serve the convenience and needs of the communities in which they are chartered to do business". ${ }^{145}$ Federal examiners evaluate a bank's community reinvestment efforts through three tests in lending, investments and service. ${ }^{146}$ These ratings are published for the public to review. The examiners can also deny applications or place conditions on the approval of deposit facilities if the CRA ratings are not adequate. ${ }^{147}$ The CRA seeks to balance a bank's benefits and burdens: banks that profit from community deposits should be encouraged to extend credit to those same communities. ${ }^{148}$

The CRA provided some direction for the Canadian Department of Finance's White Paper on "Reforming Canada's Financial Services Sector." 149 In that document, increased CRA-style disclosure was recommended, but it was noted that a full CRA regime is not warranted in Canada, and that other mechanisms could be used to promote accountability. ${ }^{150}$ Instead of the CRA, the paper proposed that all financial institutions with equity of over $\$ 1$ billion disclose information on their philanthropy, their employees' community service, and their efforts to

\footnotetext{
${ }^{143}$ Hellwig, supra note 138 at 1582; MacDonnell, supra note 32 at 49.

144 The term redlining originated from a lender's habit of outlining a specific 'poor neighbourhood' in red to indicate and exclude the area from lending as it was too high risk.

145 Emily Berkman, "Microloans as a Community Reinvestment Act Compliance Strategy” (2006) N.Y.U.J.L. \& Bus. 329.

${ }^{146}$ Ibid.

${ }^{147}$ Ibid.

${ }^{148}$ Ibid.

${ }^{149}$ Finance Canada, "Reforming Canada's Financial Services Sector: A Framework for the Future" (Finance Canada, 1999).

${ }^{150}$ Ibid.
} 
promote small businesses, micro-credit, and access to banking services. Some of these recommendations were adopted in Bill C-8, An Act to Establish the Financial Consumer Agency of Canada and to Amend Certain Acts in Relation to Financial Institutions. ${ }^{151}$ The Act created the Financial Consumer Agency, responsible for making sure banks follow through on their obligations under the Bill, and requires institutions with equity of over $\$ 1$ billion to publish an annual "Public Accountability Statement" providing the information detailed above. ${ }^{152}$ However, critics feel that this is still inadequate, as it does not provide information about demand for financing, and whether the banks are appropriately meeting the demand. ${ }^{153}$ Nor does it produce regular data based on neighbourhood (only by province), or by the characteristics of borrowers, unlike the information produced under the CRA.

The inquiries into whether Canada should move closer to the United States in adopting CRA style legislation and the role that corporate governance practices and regulation play in improving payday lending practices are important research questions as Canada moves forward with a regulatory scheme that takes into account the increasing democratization of credit.

${ }^{151}$ Bill C-8, An Act to Establish the Financial Consumer Agency of Canada and to Amend Certain Acts in Relation to Financial Institutions, 1st Sess., 37th Parl., 2001 online:

<http://www2.parl.gc.ca/HousePublications/Publication.aspx?DocId=2331014\&Languag $\mathrm{e}=\mathrm{e} \&$ Mode=1> (assented to 14 June 2001), 2001, c. 9.

${ }^{152}$ Ibid., s. 3.

153 "Comparison of Amendments set out in Bill C-8 to Financial Institution and other Laws VS. CCRC Recommendations” (2001) online: CCRC

$<$ http://www.cancrc.org/english/recomm01.html>. 
ApPEndiX A

Table 2

Provincial Payday Lending Legislation

\begin{tabular}{|c|c|c|c|c|c|c|c|c|}
\hline & $\begin{array}{l}\text { British } \\
\text { Columbia }\end{array}$ & Manitoba & $\begin{array}{l}\text { New } \\
\text { Brunswick }\end{array}$ & $\begin{array}{l}\text { Nova } \\
\text { Scotia }\end{array}$ & Ontario & $\begin{array}{l}\text { Prince } \\
\text { Edward } \\
\text { Island } \\
\end{array}$ & Quebec & Sask. \\
\hline $\begin{array}{l}\text { Title of } \\
\text { Legislation }\end{array}$ & $\begin{array}{l}\text { Bill 27, Business } \\
\text { Practices and } \\
\text { Consumer } \\
\text { Protection } \\
\text { (Payday Loans) } \\
\text { Amendment Act }\end{array}$ & $\begin{array}{l}\text { Payday Loans } \\
\text { Regulation; } \\
\text { Consumer } \\
\text { Protection Act } \\
\text { (Act) }\end{array}$ & $\begin{array}{l}\text { Bill 4, An Act } \\
\text { Respecting } \\
\text { Payday Loans }\end{array}$ & $\begin{array}{l}\text { Bill 87: } \\
\text { Consumer } \\
\text { Protection } \\
\text { Act } \\
\text { (amended) }\end{array}$ & $\begin{array}{l}\text { Bill 48: Payday } \\
\text { Loans Act (2008) } \\
\text { (PLA) }\end{array}$ & $\begin{array}{l}\text { Bill 100, } \\
\text { Payday } \\
\text { Loans Act }\end{array}$ & $\begin{array}{l}\text { Consumer } \\
\text { Protection } \\
\text { Act }\end{array}$ & $\begin{array}{l}\text { An Act } \\
\text { Respecting } \\
\text { Payday Loan } \\
\text { Agreements, } \\
\text { Payday } \\
\text { Lenders and } \\
\text { Borrowers }\end{array}$ \\
\hline $\begin{array}{l}\text { Authority to } \\
\text { set Interest } \\
\text { Rates }\end{array}$ & $\begin{array}{l}\text { Given to } \\
\text { Lieutenant } \\
\text { Governor in } \\
\text { Council, can set } \\
\text { the } \\
\text { maximum } \\
\text { amount, or } \\
\text { establish a rate, } \\
\text { formula, tariff } \\
\text { or method of } \\
\text { determining the } \\
\text { maximum } \\
\text { amount for } \\
\text {-interest, - } \\
\text { permissible } \\
\text { charges, and -the } \\
\text { total cost of the } \\
\text { loan (s. 112.02) }\end{array}$ & $\begin{array}{l}\text { That authority is } \\
\text { found in s. } 147 \text { of } \\
\text { the Act, not yet } \\
\text { enacted }\end{array}$ & $\begin{array}{l}\text { New } \\
\text { Brunswick } \\
\text { Energy and } \\
\text { Utilities Board } \\
\text { can fix the } \\
\text { ultimate cost } \\
\text { of credit } \\
\text { (37.31); can } \\
\text { also limit the } \\
\text { percentage of a } \\
\text { person's } \\
\text { income as a } \\
\text { cap on the } \\
\text { amount they } \\
\text { can borrow } \\
\text { (37.36) }\end{array}$ & $\begin{array}{l}\text { Lenders } \\
\text { can’t } \\
\text { charge } \\
\text { more than } \\
\text { maximum } \\
\text { set by Nova } \\
\text { Scotia } \\
\text { Utility and } \\
\text { Review } \\
\text { Board (18J) }\end{array}$ & $\begin{array}{l}\text { Lieutenant Governor } \\
\text { may make } \\
\text { regulations } \\
\text { prohibiting lenders } \\
\text { from making a } \\
\text { payday loan } \\
\text { agreement with a } \\
\text { borrower if the } \\
\text { amount of the payday } \\
\text { loan exceeds the } \\
\text { prescribed amounts } \\
\text { or the amounts } \\
\text { calculated according } \\
\text { to the prescribed } \\
\text { manner (s.77.19, } \\
\text { PLA) } \\
\text { Lieutenant Governor } \\
\text { may make }\end{array}$ & $\begin{array}{l}\text { Commission } \\
\text { can set a } \\
\text { maximum } \\
\text { on any } \\
\text { payments } \\
\text { that } \\
\text { contribute to } \\
\text { the cost of } \\
\text { credit (s. 11) }\end{array}$ & $\begin{array}{l}\text { Statutory } \\
\text { 35\% APR } \\
\text { cap (ss. 8, } \\
\text { 325) }\end{array}$ & $\begin{array}{l}\text { Lieutenant } \\
\text { Governor in } \\
\text { Council will } \\
\text { limit the total } \\
\text { amount that a } \\
\text { payday } \\
\text { lender can } \\
\text { charge with } \\
\text { respect to the } \\
\text { loan (s. 23) }\end{array}$ \\
\hline
\end{tabular}




\begin{tabular}{|c|c|c|c|c|c|c|c|c|}
\hline & & & & & $\begin{array}{l}\text { regulations } \\
\text { specifying limits for } \\
\text { the purposes of } \\
\text { section } 32 \text { (Total } \\
\text { Cost of Borrowing) } \\
\text { or specifying a } \\
\text { method of setting } \\
\text { limits for the } \\
\text { purposes of that } \\
\text { section. (s.77.23, } \\
\text { PLA) }\end{array}$ & & & \\
\hline $\begin{array}{l}\text { Cancellation } \\
\text { Protection }\end{array}$ & $\begin{array}{l}\text { May cancel } \\
\text { without penalty } \\
\text { before the end of } \\
\text { the next business } \\
\text { day after the loan } \\
\text { was made, or at } \\
\text { any time if the } \\
\text { loan was made in } \\
\text { contravention of } \\
\text { other protections } \\
\text { in the act or } \\
\text { without } \\
\text { informing } \\
\text { customer of } \\
\text { cancellation right } \\
\text { (s. } 112.05 \text { ) }\end{array}$ & $\begin{array}{l}\text { Found in s. } \\
\text { 149(8) of the Act, } \\
\text { not yet enacted }\end{array}$ & $\begin{array}{l}\text { May cancel } \\
\text { without } \\
\text { penalty within } \\
48 \text { hours } \\
\text { (excluding } \\
\text { Sundays and } \\
\text { holidays) of } \\
\text { the first } \\
\text { advance; or at } \\
\text { any time if } \\
\text { there is no } \\
\text { notification of } \\
\text { cancellation } \\
\text { rights (s. } \\
37.29 \text { ) }\end{array}$ & $\begin{array}{l}\text { Can cancel } \\
\text { before end } \\
\text { of business } \\
\text { day after } \\
\text { loan is } \\
\text { granted, or } \\
\text { at any time } \\
\text { if not } \\
\text { informed of } \\
\text { rights } \\
\text { (18Q) }\end{array}$ & $\begin{array}{l}\text { The borrower may } \\
\text { cancel, without any } \\
\text { reason, the agreement } \\
\text { at any time up to the } \\
\text { end of the second day } \\
\text { after the time that } \\
\text { the agreement was } \\
\text { signed (and the } \\
\text { advance received) if } \\
\text { the lender is open for } \\
\text { business. If they are } \\
\text { not open for business, } \\
\text { then the next day. } \\
\text { (s.30(1)(a) PLA) } \\
\text { If this occurs then the } \\
\text { effect is like the loan } \\
\text { never existed and the } \\
\text { borrower must pay } \\
\text { back the advance } \\
\text { given, and the } \\
\text { borrower must return } \\
\text { all fees and } \\
\text { documents associated } \\
\text { with the loan. (s.43, }\end{array}$ & $\begin{array}{l}\text { Can cancel } \\
\text { within } 48 \\
\text { hours } \\
\text { (excluding } \\
\text { Sundays and } \\
\text { holidays) } \\
\text { and any } \\
\text { other time if } \\
\text { not informed } \\
\text { of } \\
\text { cancellation } \\
\text { rights (s. 13) }\end{array}$ & NA & $\begin{array}{l}\text { May cancel } \\
\text { by end of } \\
\text { business day } \\
\text { after loan } \\
\text { agreement } \\
\text { was entered } \\
\text { into, or at any } \\
\text { time if there } \\
\text { was no notice } \\
\text { of } \\
\text { cancellation } \\
\text { rights (s. 22) }\end{array}$ \\
\hline
\end{tabular}




\begin{tabular}{|c|c|c|c|c|c|c|c|c|}
\hline & & & & & PLA) & & & \\
\hline $\begin{array}{l}\text { Information in } \\
\text { Agreement }\end{array}$ & $\begin{array}{l}\text { Must include } \\
\text { total cost of } \\
\text { credit and APR; } \\
\text { a statement that } \\
\text { interest only } \\
\text { applies to the } \\
\text { loan principal; } \\
\text { and a warning } \\
\text { that it is a "high } \\
\text { cost loan”; and } \\
\text { cancellation } \\
\text { rights (s. 112.06) }\end{array}$ & $\begin{array}{l}\text { Must include total } \\
\text { cost of credit and } \\
\text { APR; term of } \\
\text { loan; itemization } \\
\text { of all fees; and a } \\
\text { statement } \\
\text { encouraging } \\
\text { customers to take } \\
\text { questions or } \\
\text { concerns to the } \\
\text { Consumer's } \\
\text { Bureau (s. 14) } \\
\text { s.14 is in addition } \\
\text { to s.148(1)(a) [not } \\
\text { yet enacted] } \\
\text { which demands: } \\
\text { (i) states the date } \\
\text { and time of day } \\
\text { that the initial } \\
\text { advance is being } \\
\text { made or the card } \\
\text { or other device is } \\
\text { being provided, } \\
\text { (ii) states that the } \\
\text { loan is a high-cost } \\
\text { loan, (iii) gives } \\
\text { notice of the } \\
\text { borrower's right } \\
\text { to cancel the loan } \\
\text { within } 48 \text { hours } \\
\text { after receiving the } \\
\text { initial advance }\end{array}$ & $\begin{array}{l}\text { Must include } \\
\text { total cost of } \\
\text { credit and } \\
\text { APR; each of } \\
\text { the fees } \\
\text { regulated by } \\
\text { the Board that } \\
\text { apply; a } \\
\text { statement a } \\
\text { payday loan is } \\
\text { a high cost } \\
\text { loan; } \\
\text { cancellation } \\
\text { rights and } \\
\text { remedies (s. } \\
\text { 37.28) }\end{array}$ & $\begin{array}{l}\text { Lender } \\
\text { must give } \\
\text { borrower in } \\
\text { writing } \\
\text { information } \\
\text { on exact } \\
\text { amount } \\
\text { loaned, the } \\
\text { exact fees, } \\
\text { regulated } \\
\text { maximum } \\
\text { fees, and } \\
\text { cancellation } \\
\text { rights (18I) }\end{array}$ & $\begin{array}{l}\text { Lieutenant Governor } \\
\text { may make } \\
\text { regulations governing } \\
\text { information text, or } \\
\text { terms that a lender is } \\
\text { required to include in } \\
\text { a payday loan } \\
\text { agreement. Also may } \\
\text { make regulations } \\
\text { governing the form } \\
\text { that a lender is } \\
\text { required to use for } \\
\text { the information, text } \\
\text { or terms. (s.77.21-22, } \\
\text { PLA) }\end{array}$ & $\begin{array}{l}\text { At the time } \\
\text { of loan, } \\
\text { borrower } \\
\text { must get a } \\
\text { document } \\
\text { saying that it } \\
\text { is a high } \\
\text { cost loan, } \\
\text { giving right } \\
\text { to } \\
\text { cancellation. } \\
\text { (s. 12) }\end{array}$ & NA & $\begin{array}{l}\text { Before } \\
\text { entering into } \\
\text { loan, must } \\
\text { provide } \\
\text { disclosure } \\
\text { document } \\
\text { stating that } \\
\text { this is a high } \\
\text { cost loan, } \\
\text { include an } \\
\text { explanation } \\
\text { of all } \\
\text { amounts } \\
\text { charged, and } \\
\text { give notice of } \\
\text { cancellation } \\
\text { rights (s. 20) }\end{array}$ \\
\hline $\begin{array}{l}\text { Rollover } \\
\text { Prohibitions }\end{array}$ & $\begin{array}{l}\text { Cannot grant } \\
\text { rollovers; or new }\end{array}$ & $\begin{array}{l}\text { Limit on charges } \\
\text { for extension, }\end{array}$ & $\begin{array}{l}\text { No payday } \\
\text { lender shall }\end{array}$ & $\begin{array}{l}\text { No } \\
\text { rollovers, }\end{array}$ & $\begin{array}{l}\text { The lender under a } \\
\text { payday loan }\end{array}$ & $\begin{array}{l}\text { Can’t accept } \\
\text { payment for }\end{array}$ & NA & $\begin{array}{l}\text { No } \\
\text { concurrent }\end{array}$ \\
\hline
\end{tabular}




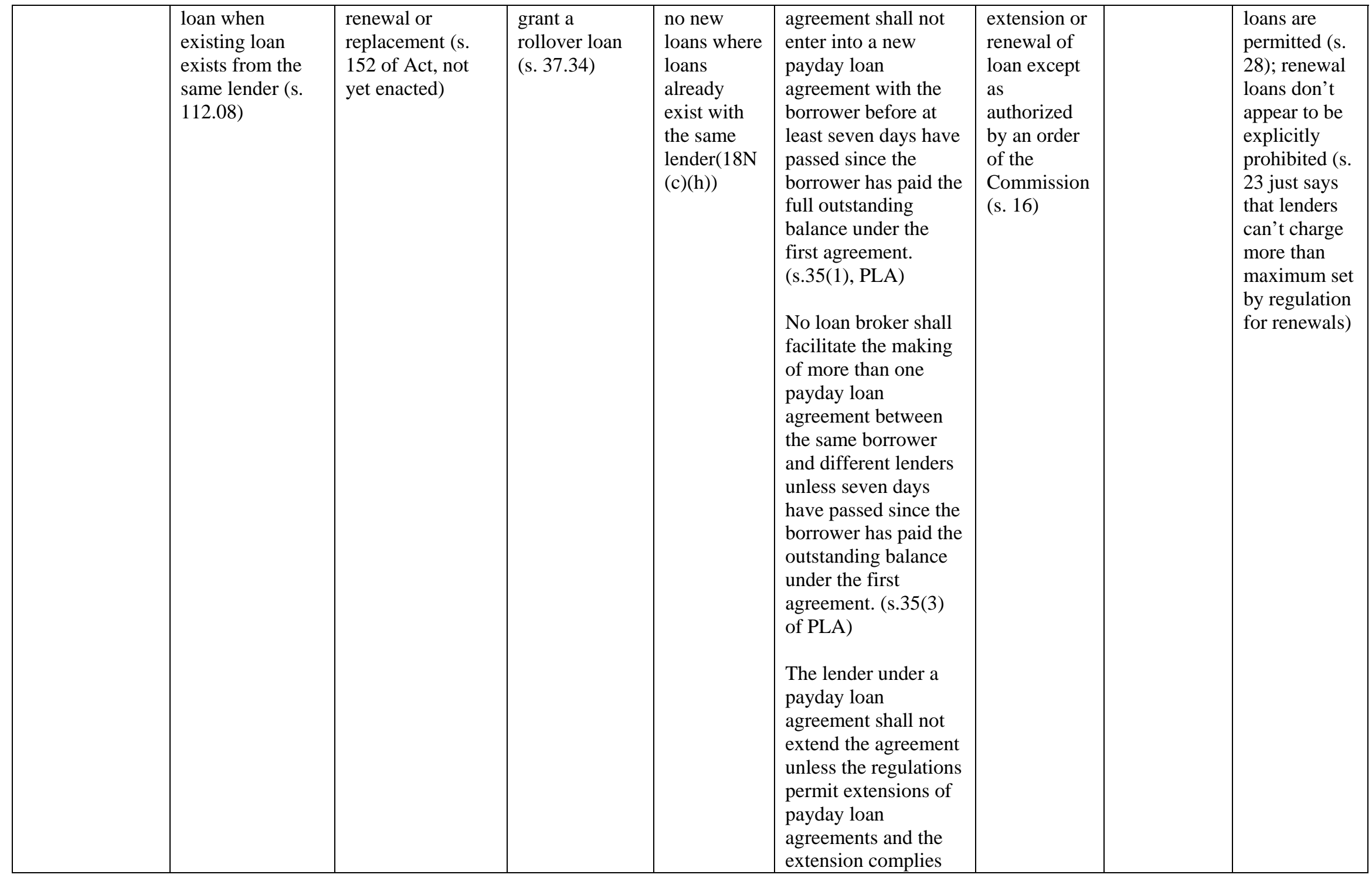




\begin{tabular}{|c|c|c|c|c|c|c|c|c|}
\hline & & & & & $\begin{array}{l}\text { with the prescribed } \\
\text { requirements. } \\
\text { (s.36(1), PLA) } \\
\text { Lieutenant Governor } \\
\text { may make } \\
\text { regulations as to the } \\
\text { definition of what } \\
\text { constitutes an } \\
\text { extension of a payday } \\
\text { loan agreement } \\
\text { (s.77.24) PLA }\end{array}$ & & & \\
\hline Licensing & $\begin{array}{l}\text { Requires payday } \\
\text { lenders to be } \\
\text { licensed and } \\
\text { regulates aspects } \\
\text { of their } \\
\text { transactions with } \\
\text { consumers. } \\
\text { Licensing and } \\
\text { compliance } \\
\text { enforcement will } \\
\text { be administered } \\
\text { by the Business } \\
\text { Practices and } \\
\text { Consumer } \\
\text { Protection } \\
\text { Authority, a not- } \\
\text { for-profit } \\
\text { organization that } \\
\text { operates at arm's } \\
\text { length from } \\
\text { government. } \\
\text { Consultation is } \\
\text { currently in } \\
\end{array}$ & $\begin{array}{l}\text { One year license } \\
\text { costs } \$ 5,500 ; \\
\text { must provide } \\
\text { sample loan } \\
\text { documents for a } \\
\$ 300 \text { loan that } \\
\text { complies with } \\
\text { regulations and an } \\
\text { undertaking from } \\
\text { director that s/he } \\
\text { knows about the } \\
\text { consumer } \\
\text { protection laws } \\
\text { (s.7, 8); licensees } \\
\text { must also provide } \\
\text { bonds (s. 10) }\end{array}$ & $\begin{array}{l}\text { May apply to } \\
\text { Minister for } \\
\text { license; must } \\
\text { pay fee and } \\
\text { provide the } \\
\text { application } \\
\text { and all other } \\
\text { documents } \\
\text { required by the } \\
\text { Minister (s. } \\
\text { 37.12-14); } \\
\text { licensee must } \\
\text { also provide } \\
\text { bond (s. 36.15) }\end{array}$ & $\begin{array}{l}\text { Need } \\
\text { permit to } \\
\text { give payday } \\
\text { loans, can } \\
\text { get permit } \\
\text { through } \\
\text { registrar } \\
\text { and must } \\
\text { pay fees } \\
\text { (18C-D) }\end{array}$ & $\begin{array}{l}\text { Each payday lender } \\
\text { (s.6(1)), and loan } \\
\text { broker (s.6(2)) is } \\
\text { required to hold a } \\
\text { license issued by the } \\
\text { Registrar. The } \\
\text { Registrar can suspend } \\
\text { or revoke a license in } \\
\text { some cases. (s.12) In } \\
\text { selected cases, the } \\
\text { applicant for a license } \\
\text { (or a renewal) is } \\
\text { entitled to a hearing } \\
\text { before the License } \\
\text { Appeal tribunal. } \\
\text { (s.13(7)) } \\
\text { An applicant for a } \\
\text { license (or renewal) } \\
\text { must disclose } \\
\text { changes in corporate } \\
\text { control and address. } \\
\text { (s.22(1)) The } \\
\text { Registrar may at any } \\
\text { time require a }\end{array}$ & $\begin{array}{l}\text { Licences are } \\
\text { required, } \\
\text { need an } \\
\text { application } \\
\text { and fee to } \\
\text { get one (ss. } \\
\text { 3-4) }\end{array}$ & $\begin{array}{l}\text { Licenses are } \\
\text { only granted } \\
\text { to lenders } \\
\text { who charge } \\
\text { a maximum } \\
\text { 35\% APR. } \\
\text { There are no } \\
\text { legal payday } \\
\text { lenders in } \\
\text { Quebec. }\end{array}$ & $\begin{array}{l}\text { Licenses are } \\
\text { required (s. } \\
\text { 5-6), and } \\
\text { lender may } \\
\text { be required to } \\
\text { provide a } \\
\text { bond or other } \\
\text { financial } \\
\text { security (s. 7) }\end{array}$ \\
\hline
\end{tabular}




\begin{tabular}{|c|c|c|c|c|c|c|c|c|}
\hline & $\begin{array}{l}\text { progress on } \\
\text { licensing } \\
\text { requirements. }\end{array}$ & & & & $\begin{array}{l}\text { licensee to provide } \\
\text { the Registrar with } \\
\text { copies of materials } \\
\text { that the licensee uses } \\
\text { or proposes to use in } \\
\text { the course of } \\
\text { conducting business. } \\
\text { (s.47(2)) (all sections } \\
\text { pertain to the PLA) }\end{array}$ & & & \\
\hline $\begin{array}{l}\text { Posted } \\
\text { Warnings }\end{array}$ & $\begin{array}{l}\text { Questions } \\
\text { pertaining to a } \\
\text { disclosure } \\
\text { regime was } \\
\text { included in the } \\
\text { BC Consultation } \\
\text { Paper. }\end{array}$ & $\begin{array}{l}\text { Sign must say } \\
\text { "Payday Loans } \\
\text { are High-Cost } \\
\text { Loans" and give } \\
\text { the cost in dollars } \\
\text { for a } \$ 300 \text { loan (s. } \\
\text { 16) } \\
\text { This is in } \\
\text { conjunction with } \\
\text { s.156 [not yet } \\
\text { enacted] } \\
\text { All lenders must } \\
\text { post signs. The } \\
\text { signs must be } \\
\text { posted } \\
\text { prominently and } \\
\text { in accordance } \\
\text { with the } \\
\text { regulations, and } \\
\text { must clearly and } \\
\text { understandably } \\
\text { set out, in the } \\
\text { form required by } \\
\text { the regulations, } \\
\text { (a) all } \\
\text { components of }\end{array}$ & $\begin{array}{l}\text { Payday lender } \\
\text { must post } \\
\text { signs that } \\
\text { clearly set out } \\
\text { full cost of } \\
\text { credit (s. 37.3) }\end{array}$ & $\begin{array}{l}\text { Governor in } \\
\text { Council can } \\
\text { make } \\
\text { regulations } \\
\text { regarding } \\
\text { the display } \\
\text { of fees, } \\
\text { charges, } \\
\text { rates and } \\
\text { products } \\
\text { offered; } \\
(18 \mathrm{U}(\mathrm{k}))\end{array}$ & $\begin{array}{l}61.1(4) \text { of the } \\
\text { Consumer Protection } \\
\text { Act requires specific } \\
\text { disclosure on the cost } \\
\text { of borrowing. }\end{array}$ & $\begin{array}{l}\text { Must post } \\
\text { signs that set } \\
\text { out, clearly } \\
\text { and } \\
\text { prominently, } \\
\text { all } \\
\text { components } \\
\text { of the cost } \\
\text { of credit, } \\
\text { including } \\
\text { fees, } \\
\text { charges, } \\
\text { interest, etc. } \\
\text { (s. 20) }\end{array}$ & NA & $\begin{array}{l}\text { Must post } \\
\text { sign setting } \\
\text { out costs of } \\
\text { all } \\
\text { components } \\
\text { of cost of } \\
\text { credit (s. 21) }\end{array}$ \\
\hline
\end{tabular}




\begin{tabular}{|c|c|c|c|c|c|c|c|c|}
\hline & & $\begin{array}{l}\text { the cost of credit, } \\
\text { including all fees, } \\
\text { charges, penalties, } \\
\text { interest and other } \\
\text { amounts and } \\
\text { consideration for } \\
\text { a representative } \\
\text { payday loan } \\
\text { transaction; and } \\
\text { (b) any other } \\
\text { information } \\
\text { required by the } \\
\text { regulations. }\end{array}$ & & & & & & \\
\hline Remedies & $\begin{array}{l}\text { Borrower } \\
\text { doesn't have to } \\
\text { pay or is entitled } \\
\text { to refund for any } \\
\text { money paid over } \\
\text { the maximum } \\
\text { set; if there is a } \\
\text { rollover, } \\
\text { borrower doesn't } \\
\text { have to pay or is } \\
\text { entitled to a } \\
\text { refund of } \\
\text { anything over the } \\
\text { principal of the } \\
\text { first loan } \\
\text { (112.10) }\end{array}$ & $\begin{array}{l}\text { An administrative } \\
\text { penalty (of } \$ 1000 \text {, } \\
\$ 3000 \text {, or } \$ 5000 \text { ) } \\
\text { can be levied if } \\
\text { there is a } \\
\text { violation of the } \\
\text { maximum credit } \\
\text { charge or limits } \\
\text { on charges of } \\
\text { renewals (s. } 19 \text { ); } \\
\text { The lender must } \\
\text { reimburse } \\
\text { borrower for fees } \\
\text { charged over the } \\
\text { maximum (s. } 147 \\
\text { of Act) or for } \\
\text { rollovers (s. } 152 \text { ). }\end{array}$ & $\begin{array}{l}\text { If there is a } \\
\text { violation of the } \\
\text { maximum cap } \\
\text { on cost of } \\
\text { credit, then the } \\
\text { lender must } \\
\text { reimburse or } \\
\text { cannot charge } \\
\text { the borrower } \\
\text { for any amount } \\
\text { charged in } \\
\text { relation to the } \\
\text { total cost of } \\
\text { credit of the } \\
\text { loan } \\
\text { (37.31(2)(b); if } \\
\text { there's a } \\
\text { rollover, } \\
\text { debtor is not } \\
\text { liable for any } \\
\text { amounts } \\
\text { relating to cost } \\
\text { of credit for }\end{array}$ & $\begin{array}{l}\text { Registrar } \\
\text { can make } \\
\text { lenders } \\
\text { reimburse } \\
\text { borrowers } \\
\text { for any } \\
\text { expenses to } \\
\text { which } \\
\text { lenders } \\
\text { aren't } \\
\text { entitled } \\
\text { (12A); If } \\
\text { the loan } \\
\text { agreement } \\
\text { says that } \\
\text { borrower } \\
\text { must repay } \\
\text { more than } \\
\text { maximum, } \\
\text { borrower } \\
\text { only has to } \\
\text { repay } \\
\text { principal }\end{array}$ & $\begin{array}{l}\text { Registrar has the } \\
\text { ability to refuse } \\
\text { licenses, prohibit the } \\
\text { use of certain } \\
\text { practices, demand } \\
\text { administer-ative fines } \\
\text { that cannot go over } \\
\text { \$10,000. (s. 59, PLA) } \\
\text { The Director can } \\
\text { make orders freezing } \\
\text { money or assets of } \\
\text { person involved in } \\
\text { proceedings that } \\
\text { infringe upon the } \\
\text { PLA. (s.52, PLA). } \\
\text { With regards to false } \\
\text { advertising: the } \\
\text { Director can also } \\
\text { order a cessation } \\
\text { and/or mandatory } \\
\text { publication of a }\end{array}$ & $\begin{array}{l}\text { If the lender } \\
\text { violates the } \\
\text { cap, must } \\
\text { return to } \\
\text { borrower all } \\
\text { consideratio } \\
\text { n given to } \\
\text { pay for cost } \\
\text { of credit in } \\
\text { loan (s. 11); } \\
\text { if lender } \\
\text { takes fees } \\
\text { for rollover, } \\
\text { must refund } \\
\text { any amount } \\
\text { charged } \\
\text { there (s. 16) }\end{array}$ & NA & $\begin{array}{l}\text { Lender must } \\
\text { refund all } \\
\text { loan charges } \\
\text { above the } \\
\text { maximum set } \\
\text { by regulation } \\
\text { (s. } 24)\end{array}$ \\
\hline
\end{tabular}




\begin{tabular}{|l|l|l|l|l|l|l|}
\hline & & & $\begin{array}{l}\text { pre-existing } \\
\text { loan (s. 37.34) }\end{array}$ & $\begin{array}{l}\text { and not cost } \\
\text { of credit } \\
(18 \mathrm{P})\end{array}$ & $\begin{array}{l}\text { correction. (s.53(1), } \\
\text { PLA.) }\end{array}$ & \\
\hline
\end{tabular}

